\title{
3D Modelling of a Hydrothermal System in a Densely Populated Urban Area - the Alfama Springs Case-Study (Lisbon, Portugal)
}

\section{Rayco Marrero-Diaz}

Involcan/LNEG

Elsa Cristina Ramalho ( $\sim$ elsa.ramalho@lneg.pt)

Laboratório Nacional de Energia e Geologia Unidade de Recursos Minerais e Geofísica: Laboratorio Nacional de Energia e Geologia Unidade de Recursos Minerais e Geofisica

João Carvalho

LNEG URMG: Laboratorio Nacional de Energia e Geologia Unidade de Recursos Minerais e Geofisica

Ruben Dias

LNEG UGHGC: Laboratorio Nacional de Energia e Geologia Unidade de Geologia Hidrogeologia e Geologia Costeira

Ana Ramada

LNEG UGHGC: Laboratorio Nacional de Energia e Geologia Unidade de Geologia Hidrogeologia e Geologia Costeira

Cláudia Pinto

Câmara Municipal de Lisboa

\section{Research Article}

Keywords: Portugal, Lisbon, Alfama, hot springs, hydrogeological modeling

Posted Date: June 22nd, 2021

DOI: https://doi.org/10.21203/rs.3.rs-514323/v1

License: (c) (i) This work is licensed under a Creative Commons Attribution 4.0 International License. Read Full License 


\section{Abstract}

In the XIX th century, the Alfama thermal and non-thermal springs were qualified as "mineral water" by the governmental authorities. But after a few years of legal usage in balneotherapy, all of them knew a constant and progressive definitive decay, and the last balneotherapic facility was abandoned and sealed more than 40 years ago. Despite their significant influence in Lisbon life along the History, their exact location is now only approximate. Nowadays, they are all buried below the city buildings, squares and streets. Since some of the Alfama springs reached temperatures up to $34^{\circ} \mathrm{C}$, groundwater from these springs can be used in a new modern spa or in district heating facilities in the heart of the city of Lisbon, if adequately recovered. But priorly, to carry out this task, a global understanding of the conceptual hydrogeological model is needed. However, the springs are located in a densely urbanized and touristic area, where geological outcrops are no longer visible and old springs' location is unknown; therefore, a review of geological and hydrogeological data and geotechnical reports was carried out to plan further research works. Adding to this exhaustive bibliographic review and data integration, new seismic reflection data were acquired, and brought some new insights on the groundwater circulation system. All these data interpretations contributed significantly to achieve a better knowledge on the main and secondary faults that control the occurrence of Alfama springs and framed them into the complex regional tectonic framework. The entire set of historical hydrogeological data, geotechnical information, and newly acquired data lead to a reasonably accurate and data supported 3D geological and hydrogeological conceptual model of the deep groundwater flow circuit. This paper describes the research work that led to the conception of the local and complex 3D hydrogeological model of the Alfama springs system. With this 3D model, the best location for a dipped well can now be envisaged, keeping in mind the narrow local urban constraints, possible future users, and stakeholders.

\section{Introduction}

The Alfama historical springs (Fig. 1) are considered as a very important cultural geoheritage in the heart of Lisbon, capital of Portugal. Although not visible today due to their location in an area with an intense urban impermeable fabric, they still have a strong but unnoticeable influence in this part of the city (Ramalho et al., 2020). As the name of Alfama district comes from the Arabic word Al-llama (which means hot fountain), Alfama waters importance to the growing and development of city of Lisbon is known for more than 2.000 years (Ramalho et al. 2020). They are part of the large number of springs that emerge along the Tagus River Estuary, from Fonte da Bica until Chafariz d'El-Rei, which means Spout Fountain and King's Fountain, respectively. These springs were studied in detail by Choffat (1895-1898), and there is a small group that was used in therapeutic treatments (Henriques, 1786), comprising the relatively warm springs (temperatures range from $24^{\circ}$ to $34^{\circ} \mathrm{C}$ ): Alcaçarias de D. Clara, Alcaçarias do Baptista, Banhos do Doutor and Alcaçarias do Duque, as well as the cold springs Bica do Jardim do Tabaco, Largo da Fundição and Bica do Sapato (Ramalho and Lourenço, 2005; 2006). Their location integrated in the urban fabric, with strong relation with the historical walls that protected the city is depicted in Fig. 1 (Ramalho et al., 2020).

The history of all these springs, as well as their use, the architectural plan of the associated building baths and the way they were exploited are detailly described in Ramalho and Lourenço $(2005 ; 2006)$; Ramalho et al. (2020) also give an historical perspective of their uses throughout the centuries, highlighting its important geoheritage role.

The Portuguese authorities that have any scientific, administrative, or inspecting jurisdiction on thermal springs development and their usage, either for hydromineral or geothermal exploitation are the National Laboratory of Energy and Geology (Laboratório Nacional de Energia e Geologia - LNEG), the Lisbon Municipality (Câmara Municipal de Lisboa - CML) and the Directorate General for Energy and Geology (Direção Geral de Energia e Geologia - DGEG). Since the 1990s, those institutions have been focused on the possibility of using this water as a geological resource (as hydromineral and/or geothermal resource) or, at least, on highlighting their potential so that possible stakeholders can use them as a green renewable energy in district heating, to heal people or to frame their importance in the city growth and History.

A 3D geological and hydrogeological conceptual model for this area was published by the first time in Marrero-Diaz and Ramalho (2015). But in this 3D model some important uncertainties persisted, as the data are mostly historic, or inferred, and a review of available information was needed. However, efforts were put to overcome this situation. Therefore, a multidisciplinary geological, hydrogeological and geophysical study was carried out with the aim of constructing a comprehensive 3D model which explains satisfactorily the Alfama groundwater circuit, through a better knowledge of the old springs, deep groundwater circulation and faults controlling groundwater uprising towards the surface.

Therefore, a data review of the Alfama springs information was conducted and integrated with newly acquired and reprocessed data. This paper describes not only the state-of-the-art but also shows the multidisciplinary geoscientific approach (comprising the result of the processing of a large dataset of geotechnical reports, carrying out urban geophysics, revising geology and historical geochemistry, carried out in an urban environment), and all the difficulties that had to be overcome to reach a more consistent and updated 3D model from the one referred in Marrero Diaz and Ramalho (2015), so that a well-support decision for the location of a future geothermal drill-hole can be taken in the near future.

\section{Geological Framework}

Lisbon is in the Western Mesozoic and Cenozoic Basins, in the Portuguese Lusitanian Basin (Lomholt et al., 1996; Rassmussen et al., 1998). This large area is partially overlaid by Cenozoic sediments of the Lower Tagus Basin (Fig. 2A) and is composed by Mesozoic detrital and carbonated sediments with more than $3 \mathrm{~km}$ of thickness. On the other hand, the Lower Tagus Basin was filled from the Paleogene by a well-known sedimentary succession of about $1.2 \mathrm{~km}$ thickness, comprised mostly by Miocene continental and estuarine deposits, overlaid by younger Holocene alluvial deposits (Moitinho de Almeida, 1986; LNEG-INETI, 2005; Pais et al., 2012). Almost the entire urban area of Lisbon is covered with Miocene deposits, but in the study area of Alfama, besides the Miocene formations depicted in Figs. $2 \mathrm{~B}$ and $3 \mathrm{C}$, Tagus estuary and related streamlines alluvium from Holocene have a strong outcrop expression too. As seen in Fig. 3C, local geology of Alfama is rather complex and discontinuous from the regional framework, with a strong structural control. 
No robust aquifer systems have been recognized in the Lisbon region, but several sedimentary formations own some aquifer ability. Among these, the carbonated and sandy formations of Lower Cretaceous or the Miocene carbonate and detrital formations can produce appreciable amounts of water (MarreroDiaz et al., 2015). These formations comprise a multilayered aquifer system (the Miocene Multilayered System (SMM)), composed by an alternation of the sandy and limestones layers and low permeability layers that act as aquitards and/or aquicludes (clays and marls) (Manuppella et al., 2011).

Table 1 shows the main hydrogeological systems and subsystems and their acronyms, after the classification made by Pinto (2003). In this table, the most important lithostatigraphic units and hydrogeologic systems and subsystems to the Alfama hot springs are shadowed in grey.

Table 1

Lithostratigraphic units in the study area, from top to base, and correspondence with the main hydrogeological systems and subsystems of Lisbon region

(modified from Pinto, 2003), and maximum thickness expected. Acronyms of each formation corresponding to the Geological Map of Portugal, sheet 34-D Lisboa, scale 1:50.000 (LNEG-INETI, 2005) and Geological Map of Lisbon County, sheet 4, scale1:10.000 (Moitinho de Almeida, 1986). The most important lithostatigraphic units and hydrogeological systems and subsystems to the Alfama hot springs are shadowed in grey.

\begin{tabular}{|c|c|c|c|c|c|}
\hline $\begin{array}{l}\text { Acronyms } \\
1: 50 k- \\
1: 10 k\end{array}$ & Lithostratigraphy & Stratigraphy & $\begin{array}{l}\text { Thickness } \\
\text { (m) }\end{array}$ & Hydrogeological System & $\begin{array}{l}\text { Hydrogeological } \\
\text { Subsystem }\end{array}$ \\
\hline$a-A+a$ & Alluvium & Holocene & 58 & \multicolumn{2}{|c|}{ Holocene Alluvional System (SAH - Sistema Aluvionar Holocénico) } \\
\hline $\begin{array}{l}\mathrm{M}_{\mathrm{Mu}}- \\
\mathrm{M}^{2} \mathrm{Va} 3\end{array}$ & $\begin{array}{l}\text { Musgueira } \\
\text { Limestones }\end{array}$ & \multirow[t]{8}{*}{ Miocene } & 6 & \multirow[t]{8}{*}{$\begin{array}{l}\text { Miocene Multilayered System } \\
(S M M)\end{array}$} & \multirow[t]{4}{*}{$\begin{array}{l}\text { Limestone-sandstone Miocene Complex } \\
\text { (CCAM - Complexo Calco-Arenítico } \\
\text { Miocénico) }\end{array}$} \\
\hline $\begin{array}{l}\mathrm{M}_{\mathrm{Pm}}- \\
\mathrm{M}^{2} \mathrm{Va}_{2}\end{array}$ & $\begin{array}{l}\text { Placuna Miocaenica } \\
\text { Sands }\end{array}$ & & 30 & & \\
\hline $\begin{array}{l}\mathrm{M}_{\mathrm{CV}}- \\
\mathrm{M}_{\mathrm{Va} 1}^{2}\end{array}$ & $\begin{array}{l}\text { Casal Vistoso } \\
\text { Limestones }\end{array}$ & & 12 & & \\
\hline $\begin{array}{l}\mathrm{M}_{\mathrm{QB}}- \\
\mathrm{M}^{2}{ }_{\mathrm{IVb}}\end{array}$ & $\begin{array}{l}\text { Quinta do Bacalhau } \\
\text { Sandstones }\end{array}$ & & 35 & & \\
\hline $\begin{array}{l}\mathrm{M}_{\mathrm{FT}}- \\
\mathrm{M}^{2}{ }_{\mathrm{IVa}}\end{array}$ & $\begin{array}{l}\text { Forno do Tijolo } \\
\text { Clays }\end{array}$ & & 60 & & $\begin{array}{l}\text { * Forno do Tijolo Complex (CAFT - } \\
\text { Complexo das Argilas do Forno do Tijolo) }\end{array}$ \\
\hline $\begin{array}{l}\mathrm{M}_{\mathrm{EC}}- \\
\mathrm{M}^{2}{ }_{\mathrm{III}}\end{array}$ & $\begin{array}{l}\text { Entrecampos } \\
\text { Limestones }\end{array}$ & & 10 & & \multirow[t]{2}{*}{$\begin{array}{l}\text { Lower Miocene Complex } \\
\text { (CMI-Complexo Miocénico Inferior) }\end{array}$} \\
\hline $\begin{array}{l}\mathrm{M}_{\mathrm{ES}}- \\
\mathrm{M}_{\|}^{1}\end{array}$ & Estefânia Sands & & 65 & & \\
\hline $\begin{array}{l}\mathrm{M}_{\mathrm{PR}}- \\
\mathrm{M}_{1}^{1}\end{array}$ & $\begin{array}{l}\text { Prazeres Clays and } \\
\text { Limestones }\end{array}$ & & 45 & & \multirow[t]{2}{*}{$\begin{array}{l}\text { * Prazeres Complex (CACP - Complexo dos } \\
\text { Prazeres) }\end{array}$} \\
\hline$\varnothing-\emptyset_{\mathrm{Bf}}$ & $\begin{array}{l}\text { Benfica Complex } \\
\text { Clays }\end{array}$ & Paleogene & $50-425$ & $\begin{array}{l}\text { *Oligocene System } \\
\text { (SO - Sistema Oligocénico) }\end{array}$ & \\
\hline$\beta-\beta$ & $\begin{array}{l}\text { Lisbon Volcanic } \\
\text { Complex Basalts }\end{array}$ & Senonian & $20-200$ & \multirow[t]{4}{*}{$\begin{array}{l}\text { Cretaceous Multilayered System } \\
\text { (SCC-Sistema Multicamada } \\
\text { Cretácico) }\end{array}$} & $\begin{array}{l}\text { *Lisbon Volcanic Complex } \\
\text { (CVL - Complexo Vulcânico de Lisboa) }\end{array}$ \\
\hline $\mathrm{C}^{2}{ }_{\mathrm{Bi}}-\mathrm{C}^{3}{ }_{\mathrm{C}}$ & $\begin{array}{l}\text { Bica Formation - } \\
\text { Crystalline } \\
\text { Limestones }\end{array}$ & Turonian & 50 & & \multirow[t]{2}{*}{$\begin{array}{l}\text { Upper Cretaceous Complex } \\
\text { (CCS-Complexo Cretácico Superior) }\end{array}$} \\
\hline $\begin{array}{l}\mathrm{C}^{2} \mathrm{Cn}^{-} \\
\mathrm{C}^{2} \mathrm{C}\end{array}$ & $\begin{array}{l}\text { Caneças Formation } \\
\text { - Marly Limestones }\end{array}$ & $\begin{array}{l}\text { Cenomanian - } \\
\text { Upper Albian }\end{array}$ & 250 & & \\
\hline $\begin{array}{l}\mathrm{C}^{1}{ }_{\mathrm{AS}} \mathrm{C}^{1}{ }_{\mathrm{A}} \\
\mathrm{C}_{\mathrm{Ba}}^{1}\end{array}$ & $\begin{array}{l}\text { Almargem } \\
\text { Sandstones }\end{array}$ & $\begin{array}{l}\text { Upper Albian - } \\
\text { Upper } \\
\text { Barremian }\end{array}$ & 120 & & $\begin{array}{l}\text { Almargem Sandstone Complex } \\
\text { (CGS-Complexo Grés de Almargem) }\end{array}$ \\
\hline
\end{tabular}

*Usually, they behave as aquitards (Marrero-Diaz et al., 2015).

The Holocene Alluvial System (SAH) and the Limestone-sandstone Miocene Complex (CCAM) generally function as leaky aquifers. The Forno do Tijolo Clays Complex (FTCC), the Oligocene System (SO) and the Lisbon Volcanic Complex (CVL) usually behave as aquitards, due to the largest amount of clays. The Prazeres Complex (CACP), although very clayey, contains more permeable sandy and carbonated intercalations. The Lower Miocene Complex (CMI) and Upper Cretaceous Complex (CCS) work as confined or semi-confined aquifers in the non-outcropping zones. The carbonated and sandy formations of the Lower Cretaceous of the Almargem Sandstone Complex (CGS) have been exploited by water wells, some of them with geothermal purposes (Marrero-Diaz et al., 2015). 
The hot springs and the Chafariz d'El-Rei named by Choffat (1895-1898; Andrade, 1935) as the Alcaçarias Group, seem to be aligned in the contact between the Estefânia Sands and Entrecampos Limestones (Banco Real), between two faults with NE-SW direction and controlled by the inverse Alfama Fault, with similar direction, acting as a strong hydrogeological barrier (Fig. 3C). The line defined by Choffat (1895-1898) included six sub-groups with convexity towards inland and both edges of this line are the Chafariz d'El-Rei and the Bica do Sapato, 1010 metres apart. Moitinho de Almeida (1972; 1986) also stated that the Alcaçarias Group is structurally framed by five faults with the same NE-SW direction. A geological profile from Moitinho de Almeida (1972) for the area of the Alfama hot springs was divided into three distinct sections, with Entrecampos (Manuppella et al. 2011) or "Banco Real" (Moitinho de Almeida, 1986) Limestones outcropping in the central section.

The Estefânia Sands from the Miocene (Burdigalian) are a depositional sequence composed by coarse to fine sands, clayey sands, siltstones, and some biocalcarenites sandstones. On the other hand, the Entrecampos Limestones ("Banco Real") are biocalcarenites with an abundant detrital fraction, sometimes with large amount of clays and often with a large amount of mollusc moulds (Manuppella et al. 2011). Both lithostratigraphic units are part of the Lower Miocene Complex (CMI) hydrogeological subsystem, in the Miocene multilayered hydrogeological system, that can reach thicknesses of more than 120 metres.

\section{Hydrogeology And Hydrochemistry Historical Data}

Stiff diagrams from the main hot springs of Alfama can be found in Ramalho and Lourenço $(2005 ; 2006)$ developed after the chemical analysis published by Almeida (1951). But as referred in Marrero-Diaz and Ramalho (2015), due to the lack of sampling points of Alfama springs nowadays, 8 old chemical analyses were selectively picked up from the bibliography (Almeida, 1951; Carvalho, 1952; Aicciaiuoli, 1944; 1952; Moitinho de Almeida, 1972; Ribeiro et al., 2005) (Fig. 3 and Table 2). From those, 7 chemical analyses correspond to Alfama springs (samples 1 to 7 ) and 1 chemical analyses (8-CEA) was selected as representative of the waters locally recharged in the sealed area upwards, namely in São Jorge Castle area (Fig. 3).

Table 2

Physical and chemical composition and geothermal characteristics of Alfama waters. Concentrations are expressed in mg/kg. From Marrero-Diaz and Ram (2015). ND: no data.

\begin{tabular}{|c|c|c|c|c|c|c|c|c|c|c|c|c|c|c|c|c|c|}
\hline Number & $\begin{array}{l}\text { Analysis } \\
\text { (Year) }\end{array}$ & $\begin{array}{l}\mathrm{T}^{\mathrm{a}} \\
\left({ }^{\circ} \mathrm{C}\right)\end{array}$ & $\mathrm{SiO}_{2}$ & $\mathrm{Na}^{+}$ & $\mathrm{Ca}^{2+}$ & $\mathrm{Mg}^{2+}$ & $\mathrm{HCO}_{3}^{-}$ & $\mathrm{Cl}^{-}$ & $\mathrm{SO}_{4}{ }^{2-}$ & $\mathrm{NO}_{3}{ }^{-}$ & TDS & $\begin{array}{l}\text { IBE } \\
(\%)\end{array}$ & Facies & $\mathrm{rNa} / \mathrm{rCl}$ & $\begin{array}{l}\mathrm{T}_{\mathrm{CH}} \\
\left({ }^{\circ} \mathrm{C}\right)\end{array}$ & $\begin{array}{l}\mathrm{D}_{\mathrm{CH}} \\
(\mathrm{m})\end{array}$ & $\begin{array}{l}\mathrm{T}_{\mathrm{MC}} \\
\left({ }^{\circ} \mathrm{C}\right)\end{array}$ \\
\hline 1-ADE & 1952 & 30.4 & 36 & 124 & 53 & 16 & 251 & 142 & 71 & 0 & 718 & 0 & $\begin{array}{l}\mathrm{HCO}_{3}- \\
(\mathrm{Cl})-\mathrm{Na}\end{array}$ & 1.35 & 57 & 1739 & 50 \\
\hline 2-ADA & 1892 & 27.6 & 31 & 147 & 70 & 22 & 113 & 190 & 95 & 30 & 667 & 12 & $\mathrm{Cl}-\mathrm{Na}$ & 1.20 & 49 & 1391 & 85 \\
\hline 3-TLS & 1853 & 30.6 & 21 & 104 & 58 & 24 & 152 & 90 & 33 & 15 & 482 & 24 & $\begin{array}{l}\mathrm{Cl}- \\
\left(\mathrm{HCO}_{3}\right)^{-} \\
\mathrm{Na}\end{array}$ & 1.77 & 33 & 696 & 70 \\
\hline 4-BBA & 1872 & 32 & ND & 218 & 69 & 9 & 110 & 183 & 228 & ND & 816 & 8 & $\begin{array}{l}\mathrm{Cl}- \\
\left(\mathrm{SO}_{4}\right)- \\
\mathrm{Na}\end{array}$ & 1.83 & - & - & - \\
\hline 5-CRI & 1892 & 27 & 33 & 63 & 70 & 17 & 150 & 79 & 38 & 17 & 450 & 17 & $\begin{array}{l}\mathrm{HCO}_{3}- \\
\mathrm{Ca}\end{array}$ & 1.23 & 52 & 1522 & 80 \\
\hline 6-JTO & 1853 & 22 & ND & 87 & 124 & 16 & 165 & 165 & 34 & 19 & 590 & 17 & $\mathrm{Cl}-\mathrm{Ca}$ & 0.82 & - & - & 55 \\
\hline 7-ML78 & 1970 & 25.5 & 27 & 103 & 114 & 11 & 378 & 138 & 43 & ND & 814 & 0 & $\begin{array}{l}\mathrm{HCO}_{3}- \\
\mathrm{Ca}\end{array}$ & 1.15 & 43 & 1130 & 30 \\
\hline 8-CEA & 2005 & 15.4 & ND & 10 & 56 & 13 & 103 & 14 & 15 & 9 & 215 & 29 & $\begin{array}{l}\mathrm{HCO}_{3}- \\
\mathrm{Ca}\end{array}$ & 1.11 & - & - & - \\
\hline
\end{tabular}

Most of the selected chemical analysis were conducted between 1850 and 1950, in times with low-accuracy analytical methods. Therefore, lon Balance Error (IBE) is higher than the recommended in 5 of the total 8 analysis ( $<8 \%$ for low-medium mineralized waters; Custodio and Llamas, 1996), decreasing the accuracy of the results.

The entire set of old spring waters from Alfama (samples 1 to 7 ) show $\mathrm{HCO}_{3}$-Cl-Ca-Na chemical facies and are similar relatively with medium to low salinity, with Total Dissolved Solids (TDS) ranging from 450 and $816 \mathrm{mg} / \mathrm{L}$, and temperatures ranging between 22 and $32^{\circ} \mathrm{C}$ (Marrero-Diaz and Ramalho, 2015). These characteristics seem to reject the possibility of a significant contribution of brackish estuarine waters.

The map of water temperature and modified Stiff diagrams (Fig. 3, D) shows a central zone with higher temperatures and mineralized $\mathrm{Cl}_{-}\left(\mathrm{SO}_{4}\right)$-Na and $\mathrm{HCO}_{3}{ }^{-}$ $\mathrm{Na}$ water types. They correspond to 1-ADE, 2-ADA, 3-TLS and 4-BBA waters, indicating that probably they are the most similar to the original deep groundwater. Colder and less mineralized $\mathrm{HCO}_{3}$-Ca or $\mathrm{Cl}-\mathrm{Ca}$ water types are found outside this central zone (Fig. 3), pointing out to a preferential deep groundwater circulation throughout limestone formations (5-CRI and 7-ML78), as well as cationic exchange Ca-Na processes in the clayey layers in the study zone (MES, MPR, Ø) (6-JTO) (Marrero-Diaz and Ramalho, 2015). The physical-chemical dispersion of Alfama springs, plotted in the Durov diagram in Marrero-Diaz and Ramalho (2015) or Ramalho et al. (2020) depicts the different degrees of mixing with cold meteoric waters locally recharged. Several geothermometers were also applied by Marrero-Diaz and Ramalho (2015) to a better constrain of the water temperature at depth, as well as the reservoir depth (Table 2). The results 
pointed out that groundwater from Alfama springs rises fast quickly upward from depths between 565 and $2957 \mathrm{~m}$ with temperatures at depth ranging from 30 to $85^{\circ} \mathrm{C}$ (Marrero-Diaz and Ramalho, 2015; Ramalho et al., 2020).

\section{New Data}

New data in the Alfama springs study result from the review of a wide set of geotechnical reports and their processing focused on the most important issues regarding this subject, geophysical prospecting carried out in the study area (reflection seismics) and new groundwater surveys from historical water springs and boreholes.

\subsection{Geotechnical reports}

Research geological works were conducted to characterize more sharply the geological structure of the lithostratigraphic units and the faults that occur in the study area, and to assess the control they make on the groundwater circulation system. To reach this goal, a systematic method was conducted, involving several tasks. As a first stage, a collection of all available geological and/or geotechnical reports on Alfama springs, which are listed in Marrero-Diaz et al. (in preparation). These ones aimed to identify and characterize the subsoil for different purposes, namely underground tunnels, sewers and existing or future buildings. From these, a preliminary analysis of 65 reports allowed a selection of 56, according to their quality and geological information. A total of 353 geotechnical boreholes and 122 geological or geotechnical profiles were georeferenced in ESRI ArcGis@ (Marrero-Diaz et al., in preparation). Each shapefile for the boreholes had as information its name, coordinates $X$ and $Y$, reports, source, and observations (Marrero-Diaz et al., in preparation). From these, the geographical distribution of the georeferenced geotechnical boreholes (Fig. 4), and this representativity was evaluated and redundant soundings were excluded (those very close, with similar information). Therefore, a new shapefile only with selected soundings was created (Fig. 4), totalizing 153 geotechnical soundings which were integrated in a database containing information after their reference (name, coordinates $X, Y$ and $Z$, report, source, observations, executor company, client company), with the following information:

- Constructive characteristics (depth);

- Hydrogeological properties (piezometric level, when available);

- Geological properties (crossed lithologies and corresponding expected lithologies).

\subsection{Lithostratigraphy}

Focusing on the selected soundings information from Fig. 4, 19 lithological classes (Table 3) were discriminated and, from these, lithostratigraphic correspondences were established with 9 units (Table 4). Lithostratigraphic correspondence was reviewed in the soundings that already had been referred or, in its absence, a new correspondence was proposed based on the specific knowledge and existing geological maps (Marrero Diaz et al., in preparation). All of them were defined according with the Geological Map of Lisbon County, sheet 4, scale 1:10 000 (Moitinho de Almeida, 1986), and the Geological Map of Portugal, sheet 34-D Lisboa, scale 1:50 000 (LNEG-INETI, 2005).

Table 3

Lithological classes considered to establish relations with stratigraphy.

\begin{tabular}{|ll|}
\hline \multicolumn{2}{|l|}{ Lithological Classes } \\
\hline Sands & Brecchias \\
\hline Clayey sands & Sandstones \\
\hline Silty sands & Clayey sandstones \\
Clays & Marly sandstones \\
\hline Sandy clays & Muds \\
\hline Silty clays & Marls \\
\hline Embankments & Silts \\
\hline Limestones & Sandy silts \\
\hline Sandy limestones & Clayey silts \\
\hline Marly limestones & \\
\hline
\end{tabular}


Table 4

Lithostratigraphic units considered in this work, corresponding stratigraphy and respective acronyms of the Geological Map of Lisbon County, sheet 4, scale 1:10 000 (Moitinho de Almeida, 1986) and the Geological Map of Portugal, sheet 34-D Lisboa, scale 1:50 000 (LNEG-INETI, 2005).

\begin{tabular}{|lll|}
\hline Stratigraphy & Lithostratigraphic Unit & Acronym (1:10 000, 1:50 000) \\
\hline Holocene & Embankments & $\mathrm{A}$ \\
\cline { 2 - 3 } & Alluvium & $\mathrm{a}$ \\
\hline Miocene (Burdigalian) & Sands with Miocene Placuna & $\mathrm{M}_{\mathrm{Va} 2}, \mathrm{M}_{\mathrm{Pm}}$ \\
\cline { 2 - 3 } & Casal Vistoso Limestones & $\mathrm{M}_{\mathrm{Va}}, \mathrm{M}_{\mathrm{CV}}$ \\
\hline Quinta do Bacalhau Sands & $\mathrm{M}_{\mathrm{IVb}}, \mathrm{M}_{\mathrm{QB}}$ \\
\hline & Forno do Tijolo Sands & $\mathrm{M}_{\mathrm{IVa}}, \mathrm{M}_{\mathrm{FT}}$ \\
\cline { 2 - 3 } & Entrecampos Limestones & $\mathrm{M}_{\mathrm{III}}, \mathrm{M}_{\mathrm{Ec}}$ \\
\hline Miocene (Aquitanian) & Estefânia Sands & $\mathrm{M}_{\|}, \mathrm{M}_{\mathrm{Es}}$ \\
\hline & Prazeres Clays and Limestones* & $\mathrm{M}_{\mathrm{l}}, \mathrm{M}_{\mathrm{Pr}}$ \\
\hline *according to Manuppella et al. (2011), this unit is attributed from Aquitanian to Lower Burdigalian.
\end{tabular}

Based on the database information, kriging interpolation method was used by means of Surfer $\circledast$ software to generate several maps (isopachs, isobaths, isohypses) regarding the lithostratigraphic units of the embankments and alluvium (Holocene), as well as a cluster unit of Undifferentiated Miocene (MarreroDiaz et al., in preparation).

\subsection{Hydrogeology and hydrochemistry}

In order to complement historical data from Alfama springs, a total of 6 water samples from different hydraulic infrastructures were collected for analyses in the study area between April and June of 2017 (Fig. 5): 1 hand-dug well (Poço da Guarda Fiscal); 1 ancient roman pool for garum manufacturing at the headquarter of the Saramago Foundation (Casa dos Bicos); 1 piezometer at Penabuquel street (Piezometro Penabuquel); 2 water tanks at formers fountains (Chafariz d'El Rei and Chafariz de Dentro); and a seepage at the former Alcaçarias do Duque spa, collected during rehabilitation works (Fig. 6).

Sampling procedures and laboratories techniques are described in detail in Marrero-Diaz et al. in preparation. From a physical-chemical point of view, water samples are relatively homogeneous, most of Cl-Na-type thermal water, with significant contamination signatures (nitrate $>100 \mathrm{mg} / \mathrm{L}$ ) as typical for urban groundwaters, related to sewage leaks, surface runoff mixing, etc. Water temperatures range from 16.4 to $21^{\circ} \mathrm{C}$, both at Chafariz D'El Rei water tank from different outlet, namely "cold" and "hot" outlets. However, none of the water samples analyzed matched the characteristics of historical thermo-mineral waters, confirming the total absence of evidence that those waters are currently emerging in the study area.

\subsection{Geophysical data acquisition}

Based on previously collected geological information of the study area, a reflection seismic survey was conducted to locate the main geological faults and, if possible, to infer their geometry and kinematics. Therefore, 5 reflection seismic profiles were carefully planned, acquired, processed, and interpreted, using different receiver spacing, according with profile location and constraints of each site. Their location is depicted in Fig. 7.

The profiles length was limited by the existing streets design and traffic intensity, since cutting the traffic in the busiest streets was an impossible task. In every profile there was, as expected, a considerable cultural noise due to the presence of nearby vehicles, demographic density, and other anthropic activities. This noise possibly decreased the data quality though a good part of it could be removed by appropriate filtering. The P-wave source had a much high power than the S-wave source and the latter contain a lower signal-to-ratio. Results obtained are satisfactory and agree with geological information where available (see later on interpretation section). Traffic was cut by the Municipal Police of Lisbon, in the streets where the profiles were acquired, during acquisition, except for profile 5.

The S-wave seismic source used to record Profiles numbers 4 and 5 was a wooden beam coupled to the ground by the front wheels of a jeep, and a hammer. The acquisition system was composed by two modules RAS-24 of Seistronix. In both profiles, $48,40 \mathrm{~Hz}$ horizontal receivers were used, spaced $1 \mathrm{~m}$ apart. The receivers were planted on the sidewalk, which is composed of small limestone cobbles. A total of 125 shot points were acquired, with a vertical stack of 5 at each site, to decrease cultural noise.

Each shot was recorded separately in a suspended mode, which allowed the operator to decide if the shot was stacked to the previous shots or alternatively, if the record had been contaminated by a passing vehicle and the record eliminated. The first shot was fired $0.5 \mathrm{~m}$ offend the southernmost receiver in both profiles, and the following shots were placed inside the receiver layout. Every 12 shots the 12 receivers behind the source position were move ahead of the receiver layout. This way we ensured a constant fold along the Sect. (18) simulating an offend receiver layout with 36 active channels and an offset to the first receiver of 0.5 .

A similar geometry was used in acquisition of Profiles 1, 2 and 3 that was carried out with P-wave sources and $48,28 \mathrm{~Hz}$ vertical receivers. The receiver spacing for these profiles was $2.5 \mathrm{~m}$, with a source-to-nearest receiver offset of $1.25 \mathrm{~m}$. The receivers moveout was identical to the S-wave data, resulting also 
in stacked sections with a coverage of 18. All receivers were planted using base plates over the asphalt. The seismic sources used to acquire the data were an accelerated $250 \mathrm{~kg}$ weight-drop (Gisco AWD 550T) in Profile 1 and hammer and plate (1 and 2) for Profiles 2 and 3 . The hammer and plate had energy enough to register the first breaks of the most distant receivers and avoided the presence of guided waves generated by the AWD source, much more energetic and a using a wider plate. A total of 40 shot points were given for Profile 1, with a vertical stack of 2 at each shot point due to heavy traffic nearby, resulting in a total length of approximately $102 \mathrm{~m}$ for this stacked section. For Profiles 2 and 3 were fired a total of 38 shot points each one, with a vertical stack of 5 , from which resulted a total stacked length of also approximately $102 \mathrm{~m}$.

Considering the acquisition geometry used in the acquisition of P-wave and S-wave data and the seismic velocities in the area obtained from the analysis of first break data, we estimate that investigation depths reached approximately 200 m, possibly 300 m and around 140 m, respectively, for P-wave and S-wave data.

Data processing was carried out with Seismic Processing Workshop (SPW). S-wave data processing (Profiles 4 and 5) included the following steps: geometry introduction, vertical stack (5 files in each shot point), trace edits, static corrections (elevation), frequency filtering, amplitude correction, notch filter (centre 50 $\mathrm{Hz}$ ), mute of first arrivals, FK filter, spectral withening between $40-120 \mathrm{~Hz}$, velocity analysis, NMO correction and stacking.

Refraction statics with two-layer models were also applied (Farrell and Euwema, 1984), but they did not provide adequate results. Deconvolution was also attempted, but it was not effective, possibly due to the variations of source signal (Yilmaz, 2001) due to the presence of embankments in the study area. The processing chain for P-wave data (Profiles 1, 2 and 3) was similar to the S-wave profiles. Only a dip filter was added to the above-mentioned steps, to eliminate the guided waves observed in Profile 1.

For each step of data processing, mostly for FK filters, dip filters and spectral withening, the shot gathers were carefully inspected, to avoid generation of artefacts and their stacking. Velocity analysis was conducted with two different techniques: constant velocity stack panels and hyperbolic velocity picking. While the first usually results in practical and fast results, the second method respects the seismic velocities observed in the shot gathers (Yilmaz, 2001). Residual statics were not used to avoid erasing (through cycle skipping) the presence of geological faults (Cox, 1999; Carvalho et al., 2012).

Using the processing velocities, the profiles were migrated, and depth converted. The migration algorithm used was phase-shift (Gazdag, 1978) with prior partial migration applied through the application of a dip moveout (DMO) operator in FK domain (Hale, 1984) followed by velocity analysis. The vertical resolution of the data, using the processing velocities, the frequency content of the data and the Widess criterion (Widess, 1973), is approximately $0.5 \mathrm{~m}$ for the S-wave profiles, and $2 \mathrm{~m}$ for P-wave data.

\section{Results}

\subsection{Lithostratigraphy}

The embankments, over the alluvium, were identified in almost all the geotechnical soundings in the study area from Fig. 5; their thickness increases in the riverbank (with $18 \mathrm{~m}$ as maximum value) and lower thicknesses in the surroundings of the São Jorge Castle, at north, with the top of the Alluvium unit at shallower depths, in some areas 1 meter (Fig. 8). However, the geotechnical soundings where the Alluvium unit was present are strict to the riverbank and to Tagus estuary (Fig. 8A). In these, there is an increasing trend of thickness towards the river zone; however, the highest thicknesses values are registered in the Praça do Comércio area, reaching $40 \mathrm{~m}$, where undifferentiated Miocene was found at depths of $50 \mathrm{~m}$ (see Figs. 7A and 7B). This feature is probably related with an alluvium fossilized Miocene paleovalley.

The isobaths map of top of Undifferentiated Miocene (Fig. 8B) allows analyzing substrata from a global point of view, with a depth increasing from North towards South and the highest depths (50 meters) are once again in Praça do Comércio.

The isohypse maps of top of Alluvium and Undifferentiated Miocene units, in meters above sea level (m.a.s.I.), were imported to ESRI ArcSceneC , allowing a 3D visualization (Fig. 9). The strongly influence of the terrain morphology increases the values from South towards North, as expected. This is an important feature to consider in data interpretation, since S. Jorge Castle hill causes major differences in Embankments and Alluvium thicknesses deposits. As depicted in Fig. 9, the top of Undifferentiated Miocene ranges between -50 and +90 (m.a.s.I.), while the top of Alluvium ranges between -17 and +4 (m.a.s.I.).

Finally, isobaths maps of the litostratigraphic units described in Table 4 were also generated by means of Surfer@ software (Fig. 10).

Figure 11 depicts the 3D model of the surfaces from Fig. 10, corresponding to the top of Miocene formations $\left(M_{V a 2}, M_{V a 1}, M_{\mid V b}, M_{\mid V a}, M_{\| l}, M_{\| l}\right.$ e $\left.M_{1}\right)$ defining the 3D geological model.

\subsection{Hydrogeology and hydrochemistry}

As referred in Marrero-Diaz et al. (in preparation) the analyzed physical and chemical parameters of water samples from Chafariz de Dentro, Poço da Guarda Fiscal, Cahafariz d'El-Rei, Largo das Alcaçarias and Casa dos Bicos did not have any thermal characteristics. Instead, they showed either a mix with shallow contaminated water with high concentration in fecal coliforms, maybe resulting from losses in the sewage networks or a significant mix of brackish or salt water from the Tagus Estuary (Marrero-Diaz et al., in preparation). Therefore, the results were not considered to be relevant in this study, although some considerations could be inferred, regarding the 3D conceptual model.

As concluded from the analysis of the geotechnical reports, groundwater flow direction seems to follow the present streamlines, from the São Jorge Castle towards the Tagus Estuary, as seen in the piezometric level interpolated from geotechnical soundings (Marrero-Diaz et al. in preparation). It is important to

Page $7 / 22$ 
highlight the existence of relatively high piezometric levels, some of them showing artesianism, such as the remarkable case of borehole ML-78 (Moitinho de Almeida, 1972; Ramalho et al., 2020), located in the Largo do Chafariz de Dentro, or at the Terreiro do Paço transport terminal (Ramalho and Lourenço, 2006).

The existence of fault(s) or low permeability formations cross to groundwater flow lines could be the cause of the high piezometric levels observed in the study area (Marrero-Diaz et al., in preparation).

\subsection{Geophysics}

Profiles 1 and 2 (P-wave), with a strong E-W orientation component, show the geological-seismic layers almost sub horizontal, while profiles 4 and 5, with a strong N-S orientation, show a layer deepening approximately towards S, of about 15-20 degrees. Profile 3 shows an intermediate dip of the seismic reflectors, in agreement with the expected dip of the geological layers. Geological faults were interpreted in the geophysical data as deep-rooted faults, once they reach the base of seismic profiles $(200-300 \mathrm{~m})$.

The time migrated (top) and depth converted seismic sections with fault interpretation overlaid (bottom) are shown in Figs. 12 and 13 for P-wave and S-wave, respectively. Vertical arrows are coincident with the intersection or prolonging of interpreted faults towards surface (dashed red lines). Blue arrows represent the mapped faults in Geological Map of Lisbon County, sheet 4, scale 1:10 000 (Moitinho de Almeida, 1986). Red arrows represent non-mapped faults, identified through observation of the seismic profile. Small, dipped arrows indicate, when possible, and in a proposal way, fault movement, based either in mapping (blue colour) or suggested by the seismic profile interpretation (red colour).

Individual interpretations for each seismic profile from Figs. 12 and 13 are presented as follow:

- Profile 1 (Fig. 12): this profile has a strong E-W orientation and was conducted with the aim to cross the "Alfama Fault", a major fault depicted in the geological maps (Moitinho de Almeida, 1986; LNEG-INETI, 2005), which possibly facilitates a relatively fast groundwater movement from depth to surface. It was possible to identify two major normal, subvertical faults, deep rooted and located at the expected zone of the profile. It shows the geological-seismic layers almost sub horizontals.

- Profile 2 (Fig. 12): its goal was to cross a mapped strike slip fault and it has a strong orientation component E-W. Normal or strike slip faults, possibly interconnected, reach the base of the seismic profiles $(200-300 \mathrm{~m})$. The seismic reflectors are almost sub-horizontal, with a slight dip to SW.

- Profile 3 (Fig. 12): Profile sited with the goal of investigating the "Alfama Fault" as in Profile 1, which, however, showed an inverse kinematic. Again, the fault reaches the base of the seismic profiles (200-300m) and seismic reflectors are nearly sub-horizontal, with a very tenuous dip to SSW.

- Profile 4 (Fig. 13): had the aim of crossing a secondary fault; the S-wave profile shows discontinuous reflectors, possibly due to the high level of noise present in the city and the lower energy S-wave source when compared to the P-wave data. Nevertheless, the data also indicates a high level of faulting and deformation, as expected from its location, which is close to the main inverse fault and over the up-thrust block. The reflectors dip is approximately towards S, about 15-20 degrees.

- Profile 5(Fig. 13): had the aim of crossing the main thrust fault mapped, unidentified in this area. The S-wave profile shows little coherent reflectors, possibly due to both high cultural noise/small source energy and strong deformation expected at this location. Despite the profile's poor quality, two major faults are interpreted, suggested by different dips of the tenuous reflectors visible in the stacked section. It is not possible to infer the fault's geometry, but the strong deformation and lack of reflectors coherency point to the presence of a thrust fault, as mapped.

After their individual interpretation, reflection seismic profiles were incorporated into the rest of the compiled and processed information, which allowed refining the geological 3D model of the study area.

\section{Discussion}

The geophysical prospecting (seismic profiles) interpretation was integrated into the other processed information, namely the geological surface created by means of the geotechnical information, outcrop formations of geological mapping at scale 1:50 000, faults mapped by Moitinho de Almeida (1972; 1986) as well as the piezometry (Fig. 14).

The origin of thermo-mineral waters of Alfama has historically been associated with a series of sub-vertical local faults with NW-SE orientation, dipping towards SW (Andrade, 1935; Moitinho de Almeida, 1972), which could favor groundwater circulation from deep formations towards surface. From the seismic profiles, the existence and location of numerous deep-rooted faults were confirmed.

Some of the faults inferred from the seismic profiles show a good spatial correspondence with those mapped in the Geological Map of Lisbon County, sheet 4, scale 1:10.000 (Moitinho de Almeida, 1986), namely those represented in Profiles 1, 2, 3 and 5 (Figs. 11 and 12). However, other faults were identified without mapping correspondence, that may be also controlling groundwater circulation associated to the Alfama springs, namely those from seismic profile 4 (Fig. 13). This fault set is located in the central zone of study area, where the warmest springs emerged, right next to the Alcaçarias do Duque, Alcaçarias de D. Clara and Tanque das Lavadeiras (Ramalho et al., 2020).

In addition, there are other situations where the faults geometry inferred from seismic profiles is not compatible with fault mapping. That is the case of Profile 1, where both identified faults (Fig. 12), apparently with normal geometry, do not have correspondence with the inverse fault (called Alfama Fault) of the Geological Map of Lisbon County, sheet 4, scale 1:10.000 (Moitinho de Almeida, 1986). The explanation proposed in this study concerning this discrepancy lies on the northern location of the Alfama Fault, prolonging to SW, at least to the westernmost part of Praça do Comércio (Fig. 15). In this area, the deepest zone of the Top of Undifferentiated Miocene (Fig. 8) and the thickness of the post-Miocene lithostratigraphic units (embankments and alluvium, Fig. 8A and 9) are consistent with the existence of a fossilized palaeovalley in the Miocene formations, probably related with a Tagus River affluent crossing the Baixa 
Pombalina area in its western side, installed in a fault zone. Although in the profiles from the geotechnical reports consulted, this geomorphological accident was not interpreted as a fault, the study of the depositional sequence of the lithostratigraphic units indicates that the installation of the palaeovalley is related with a sub-vertical fault with normal geometry (green fault in Fig. 16). Its behavior will be similar to the secondary faults that can be seen in the Alfama area, probably suggesting the prolonging towards SW of the Alfama Fault.

Geometry and kinematics of the faults in Geological Map of Lisbon County, sheet 4, scale 1:10 000 (Moitinho de Almeida, 1986) are not compatible with a geodynamic model where maximum compression is NW-SE, possibly associated with Betic compression (Ribeiro et al., 1990) (Fig. 16, up). In this geodynamic model and with the geometry of the main accident (the Alfama Fault), the main plan near vertical, the accident blocks. Therefore, it must be admitted that the main accident had suffered a horizontal left strike slip movement, with a vertical inverse movement component (Fig. 16, bottom). In this case, the orientation of maximum compression should be near NNW-SSE (yellow arrows in Fig. 16, bottom). NE-SW, sloping to the Alfama Fault may be considered secondary structures related with the main structure. In a way that the obtained results are compatible, they eventually also have a slight left horizontal movement component. To harmonize obtained results with regional geology (e.g. Rasmussen et al., 1998), we can consider that the Alfama Fault will correspond to a regional fault with left strike slip movement, in Miocene times.

The conceptual updated and refined 3D model for the Alfama waters is depicted in Fig. 17. It is the update of the model presented in Marrero Diaz and Ramalho (2015), with the interpretation of data from this study.

The origin for the faults that allowed the outcropping of Alfama springs will possibly by the identified fault set of the area, namely faults F3, F3' and F4, associated with the tectonic accident inverse left strike slip movement (the Alfama Fault). At shallow depths, thermo-mineral waters mix in several degrees with meteoric waters, cold and contaminated, either from brackish estuarine water (blue arrow) or locally recharged flowing through the Miocene permeable formations (white arrows).

\section{Final Remarks}

Considering the dense urban fabric of the area, the surface position of drilling of a dipping well is very limited. The permit area of Alfama, giving to the Lisbon Municipality the rights for prospecting and exploration of mineral water, is also coincident with the protection zone of Alfama Waters in the Lisbon Master Plan Revision (PDM, 2012), showed in Ramalho et al. (2020). Therefore, any future drillhole will have to simultaneously be either hydrogeologically favorable or have a favorable urban location.

Following the previous knowledge in other thermal waters, such as Caldas da Rainha (Marques et al., 2010) and low-medium geothermal gradients (c. $f$. Correia and Ramalho, 2010) in the Portuguese Occidental Meso-Cenozoic Basin, the existence of warm springs in Alfama area can only be explained by the favorable conjunction of groundwater circulation in deep aquifer formations and faults or geological structures important enough to allow groundwater uprising towards the surface.

The results of the detailed geophysical and geological investigation carried out in this study allowed confirming the existence of a regional tectonic feature and a set of associated secondary faults, that may favor the fast groundwater uprising from depth towards the surface. However, the results of the hydrogeological investigation confirmed the absence of actual springs with thermo-mineral characteristics (Marrero-Diaz et al., in preparation). Sampled deep circulation groundwaters from heritage springs seem to be mixed, either with contaminated water (non-meteoric, possibly city sewers) or with brackish estuarine water ( $\mathrm{Na}-\mathrm{Cl})$, or even both (Marrero-Diaz et al., in preparation).

Geothermal calculations applied to the historical analysis of Alfama springs, although with some uncertainty, indicated equilibrium temperatures ranged between 30 and $85^{\circ} \mathrm{C}$ in the aquifer. Assuming a regional geothermal gradient of $23^{\circ} \mathrm{C} . \mathrm{km}^{-1}$ and an average environmental temperature of $17^{\circ} \mathrm{C}$, it would be targeted at depths ranging between 500 and 3000 m (Marrero-Diaz and Ramalho, 2015; LNEG, 2020).

Thanks to the 3D hydrogeological model of the Alfama area, that that processed and integrated all the relevant features that control the location for a future exploitation and exploration hydrogeological/geothermal borehole. It can therefore be much more accuracately chosen, inside the limits of this legal permit. This choice will however depend on the adequate space, who will be the ultimate beneficiary of geothermal energy, or physical constraints related with the urban fabric. The 3D model information is nevertheless of outmost importance for the future definition of a well characteristics. By observing the 3D model, these will ultimately depend on its location, namely regarding its possible depth, dipping, predicted productive depths, predicted temperatures and hydrochemical characteristics.

\section{Declarations}

\section{Competing interests}

The authors declare no competing interests.

\section{Aknowledgements}

A research work under these difficult logistic characteristics was only possible thanks to several key institutions and many priceless individuals. Therefore, authors wish to thank the Polícia Municipal of Lisboa (PML), the Serviço Municipal de Proteção Civil of Lisboa (SMPC), the Lisbon Municipality (Câmara Municipal de Lisboa, CML), Direção Geral de Energia e Geologia (DGEG) and Laboratório Nacional de Energia e Geologia (LNEG). The authors also are in doubt with Paulo Henriques (SMPC), Manuela Lima, Carlos Fernandes (CML), Carla Lourenço (DGEG) and António Abreu, Joaquim Fernandes, Carlos Martins, Fernando Caneiras, Jaime Leote do Rego, José Sampaio, Carla Midões, Judite Fernandes, Augusto Costa e María Luisa Ribeiro (LNEG) for all the help and 
support they provide, in so many ways, either in field work or by providing the necessary logistic conditions to carry out this research. R. Marrero-Diaz also acknowledges FCT (the Portuguese Science and Technology Foundation) for the post-doc scholarship SFRH/BPD/2011.

\section{References}

1. Acciaiuoli, L.,1944. Águas de Portugal - Vol. V. Direcção Geral de Minas e Serviços Geológicos, Lisboa

2. Almeida, A., 1951. Lisboa, Capital das Águas. Revista Municipal, Publicação Cultural da Câmara Municipal de Lisboa. Separata, $49-50: 41$.

3. Andrade, C. F., 1935. Memória descritiva sobre a modificação a introduzir na actual captagem da "Alcalina" das Alcaçarias do Duque. 47p.

4. Carvalho, A. H., 1952. Relatório da análise da água das Alcaçarias do Duque.

5. Carvalho, J. M., Berthou, P. Y., Silva, L.F., 1990. Introdução aos Recursos Geotérmicos da Região de Lisboa, Book tribute to Carlos Romariz - Applied and Economical Geology Section, Lisbon, 332-356.

6. Choffat, P., 1895-1898. Les eaux d'alimentation de Lisbonne - rapport entre leur origine géologique et leur composition chimique. Comunicações da Direcção dos Trabalhos Geológicos de Portugal. III: 145-198.

7. Correia, A., Ramalho, E. C., 2010. Updated heat flow density Map for Portugal. Proceedings of the World Geothermal Congress 2010, Bali, Indonesia.

8. Cox, M., 1999, 'Static corrections for seismic reflection surveys', Soc. Explor. Geophys., 532.

9. Custodio, C., Llamas, M. R., 1996. Hidrología Subterránea, 2ª Ed., Barcelona, 1-2: 2359.

10. Farrell, R. C., Euwema, R. M., 1984. Refraction Statics, IEEE, 72(10): 1316-1329.

11. Gazdag, J., 1978. Wave-equation migration by phase shift, Geophysics, 43: 1342-1351.

12. Henriques, F. F., 1726. Aquilégio Medicinal. Edição fac-similada de 1998. Instituto Geológico e Mineiro. Lisboa. 288.

13. Keller Grundbau GmbH, 1999. Relatório Final dos Trabalhos Reconhecimento Geológico e Geotécnico na Zona do Túnel Rodoviário da CML Volume II, Metropolitano de Lisboa, E. P. Relatório interno, não publicado.

14. LNEG-INETI, 2005. Sheet 34-D Lisboa da Carta Geológica de Portugal na escala 1:50.000. $2^{\text {nd }}$ Edition, Lisboa.

15. LNEG, 2020. https://sig.Ineg.pt/server/services/AtlasGeotermico/MapServer/WMSServer, accessed on the $19^{\text {th }}$ february 2021.

16. Lomholth, S., Rasmussen, E. S., Andersen, C., Vejbaek, O. V., Madsen, L., Steinhardt, H, 1996. Seismic interpretation and mapping of theLusitanian Basin, Portugal, Report, MILUPOBAS project, EC Contract No. JOU2-CT94-0348, Geological Survey ofDenmark, 70 pp.

17. Manuppella, G., Ferreira, A. B., Dinis J., Callapez, P., Ribeiro, M. L., Pais, J., Rebêlo, L., Cabral, J., Moniz, C.; Baptista, R., Henriques, P., Falé, P., Lourenço, M. C., Sampaio, J., Midões, C.; Zbyszewski, G., 2011. Notícia Explicativa da Carta Geológica de Portugal à Escala 1:50 000, Folha 34-B, Loures. Unidade de geologia e Cartografia Geológica, Laboratório Nacional de Energia e Geologia. Lisboa, 57.

18. Marques, J. M., Eggenkamp, H. G. M., Graça, H., Carreira, P. M., Matias, M. J., Mayer, B., Nunes, D., 2010. Assessment of recharge and flowpaths in a limestone thermomineral aquifer system using environmental isotope tracers (Central Portugal). Isotopes in Environmental and Health Studies, 46(2): 156-165 (doi.org/10.1080/10256016.2010.491152)

19. Marrero-Diaz et al., in preparation. Hydrogeological investigation in the hidden hydraulic structures of Alfama, Lisbon, Portugal. To submit to Comunicações Geológicas.

20. Marrero-Diaz, R., Costa, A., Duarte, L., Ramalho, E., Rosa, C., Rosa, D., 2013. Principales características y limitaciones del acuífero Cretácico Inferior en la región de Lisboa para su potencial uso como recurso geotérmico de baja entalpía. Congresso Aspectos Tecnológicos e Hidrogeológicos de la Geotermia, Barcelona, Espanha, 157-163.

21. Marrero-Diaz, R., Ramalho, E., Costa, A., Ribeiro, L., Carvalho, J., Pinto, C., Rosa, D., Correia, A. 2015. Updated Geothermal Assessment of Lower Cretaceous Aquifer in Lisbon Region, Portugal. World Geothermal Congress, Melbourne, Australia, $19^{\text {th }}-25^{\text {th }}$ April.

22. Marrero-Diaz, R. and Ramalho, E. C., 2015. Características geoquímicas das antigas nascentes termominerais de Alfama (Lisboa, Portugal): estudo preliminar do seu potencial geotérmico e hidromineral. Comunicações Geológicas (2015), 102: Especial I, X Congresso Ibérico de Geoquímica/XVIII Semana de Geoquímica, Lisboa.

23. Moitinho de Almeida, F., 1972. Parecer hidrogeológico sobre uma sondagem executada no Largo do Chafariz de Dentro para o Metropolitano de Lisboa. Revista da Faculdade de Ciências, $2^{\text {a }}$ série. C - Ciências Naturais, XVII(1): 187-196.

24. Moitinho de Almeida, F., 1986. Carta Geológica do Concelho de Lisboa, sheet 1, 2, 3 and 4, scale 1:10.000, Serviços Geológicos de Portugal, Lisboa.

25. Pais J., Cunha P. P, Pereira, D., Legoinha, P., Dias, R., Moura, D., Brum, A., Kullberg, J. C., González-Delgado, J. A., 2012. The Paleogene and Neogene of Western Iberia (Portugal). A Cenozoic Record in the European Atlantic Domain. Springer Briefs in Earth Sciences 1.

26. PDM, Plano Diretor Municipal de Lisboa, 2012. Diário da República, $2^{a}$ série, $n^{\circ} 168$, de 30 de agosto - Aviso nº $11622 / 2012$

27. Pinto C., 2003. Estudo dos Recursos Hídricos Subterrâneos do Concelho de Lisboa - Zona Ocidental. Relatório de Estágio Profissionalizante. FCUL, Lisboa, $190 p+$ anexos.

28. Ramalho, E. C. and Lourenço, M. C., 2005. As águas de Alfama - memórias do passado da cidade de Lisboa. Revista da APRH, v. 26, pp.101-112.

29. Ramalho, E. C., Lourenço, M. C., 2006. As águas de Alfama - a riqueza esquecida da cidade de Lisboa. Boletim de Minas, 40(1): 5-24.

30. Ramalho, E. C., Marrero-Diaz, R., Carvalho M., Dias R., Ramada, A., Pinto C., 2020. Alfama Springs, Lisbon, Portugal: cultural geoheritage throughout the centuries. Geoheritage, 12:74, https://doi.org/10.1007/s12371-020-00484-1

31. Rasmussen, E.S., Lomholt, S., Andersen, C., Vejbaek, O. V., 1998. Aspects of the structural evolution of the Lusitanian Basin in Portugal and the shelf and slope area offshore Portugal, Tectonophysics, 300: 199-225, https://doi.org/10.1016/S0040-1951(98)00241-8

Page $10 / 22$ 
32. Ribeiro, D., Guerreiro, J., Duarte, J., 2005. Estudo Hidrogeológico do Bairro de Alfama. BsC Thesis, Faculdade de Ciências da Universidade de Lisboa, Lisboa, $75+$ annexes.

33. Yilmaz, O., 2001. Seismic Data Analysis, Society of Exploration Geophysicists, Tulsa, USA.

\section{Figures}

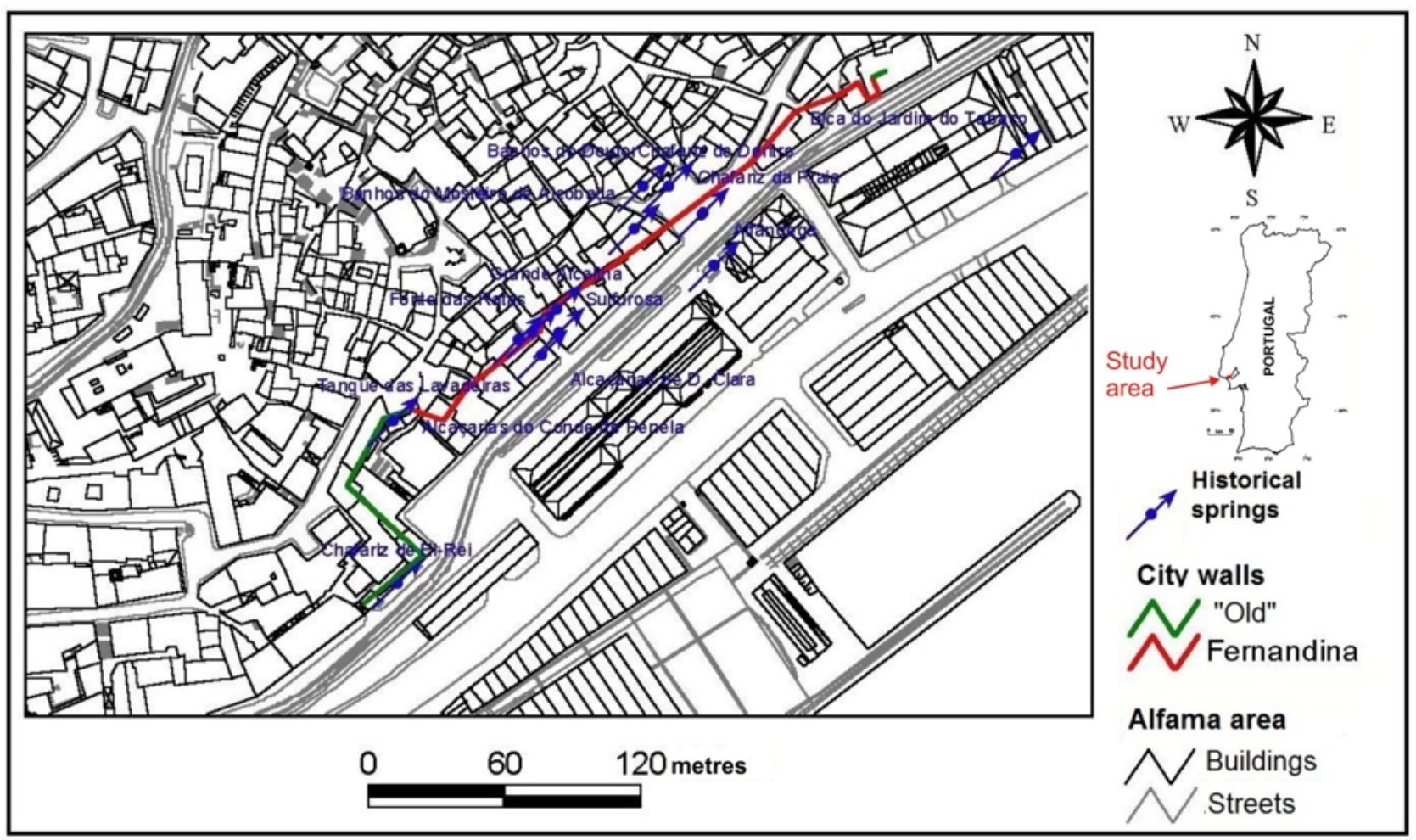

Figure 1

Location of Alfama springs and of both city Lisbon Walls: the "Cerca Velha" (Old Wall) and the "Cerca Fernandina" (Fernandina Wall)" (Ramalho and Lourenço 2005 , 2006). Note: The designations employed and the presentation of the material on this map do not imply the expression of any opinion whatsoever on the part of Research Square concerning the legal status of any country, territory, city or area or of its authorities, or concerning the delimitation of its frontiers or boundaries. This map has been provided by the authors. 


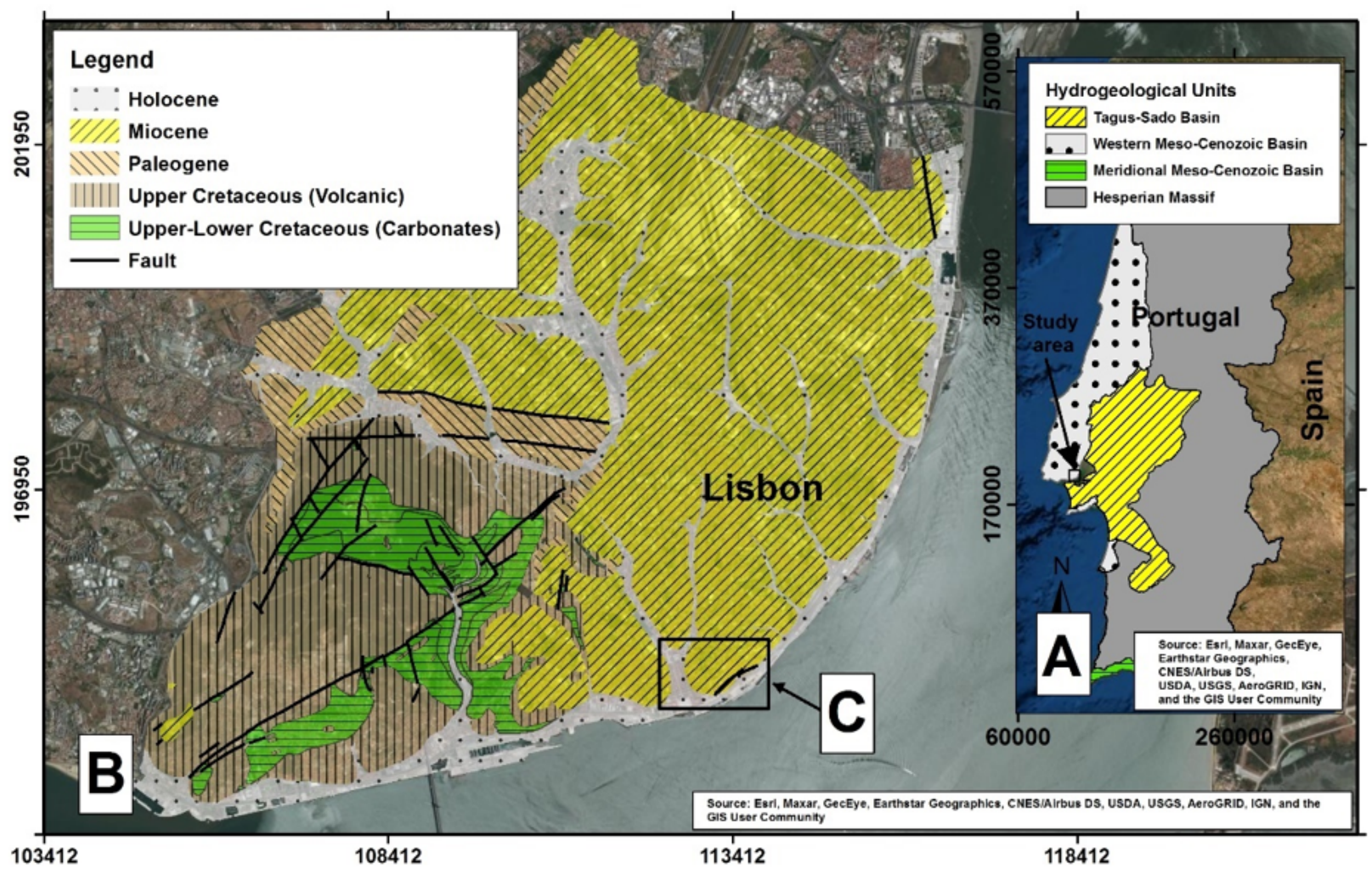

Figure 2

A) Main hydrogeological units of Portugal. B) Simplified geology of Lisbon County modified from the Geological Map of Portugal, sheet 34-D Lisboa, scale 1:50.000 (LNEG-INETI, 2005). C) Study area. Note: The designations employed and the presentation of the material on this map do not imply the expression of any opinion whatsoever on the part of Research Square concerning the legal status of any country, territory, city or area or of its authorities, or concerning the delimitation of its frontiers or boundaries. This map has been provided by the authors.

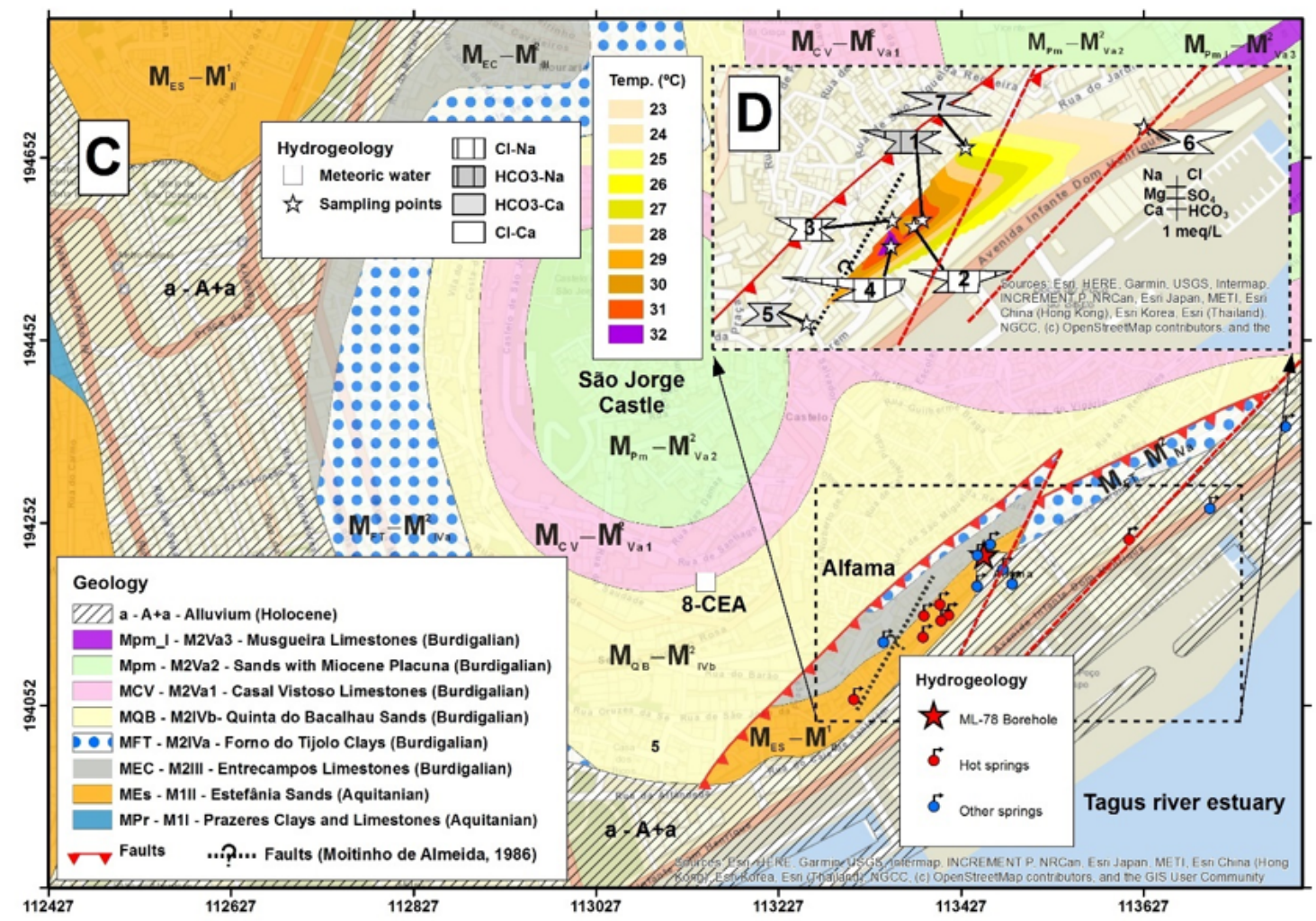

Figure 3 
C) Geology of the study area, modified from the Geological Map of Lisbon County, sheet 4, scale 1:10 000 (Moitinho de Almeida, 1986) (Fig. 2C for general location); D) Amplified map of the historical location of the old Alfama springs and borehole ML-78, corresponding temperatures, and modified Stiff diagrams (based on GoogleEarth Maps@). Note: The designations employed and the presentation of the material on this map do not imply the expression of any opinion whatsoever on the part of Research Square concerning the legal status of any country, territory, city or area or of its authorities, or concerning the delimitation of its frontiers or boundaries. This map has been provided by the authors.

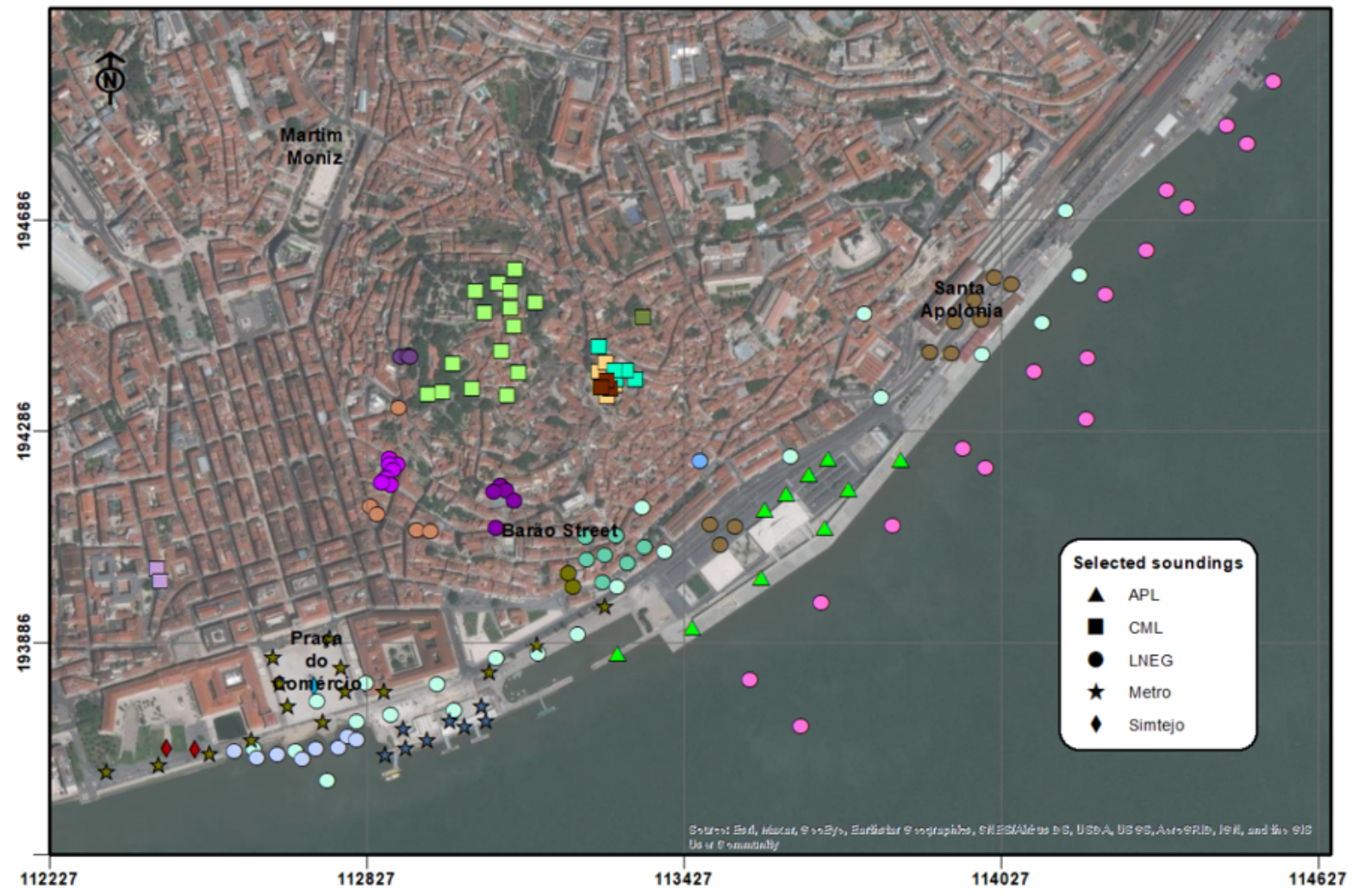

\section{Figure 4}

Location of the 153 selected geotechnical soundings, grouped by source. Base: GoogleEarth Maps $\odot$. Note: The designations employed and the presentation of the material on this map do not imply the expression of any opinion whatsoever on the part of Research Square concerning the legal status of any country, territory, city or area or of its authorities, or concerning the delimitation of its frontiers or boundaries. This map has been provided by the authors. 


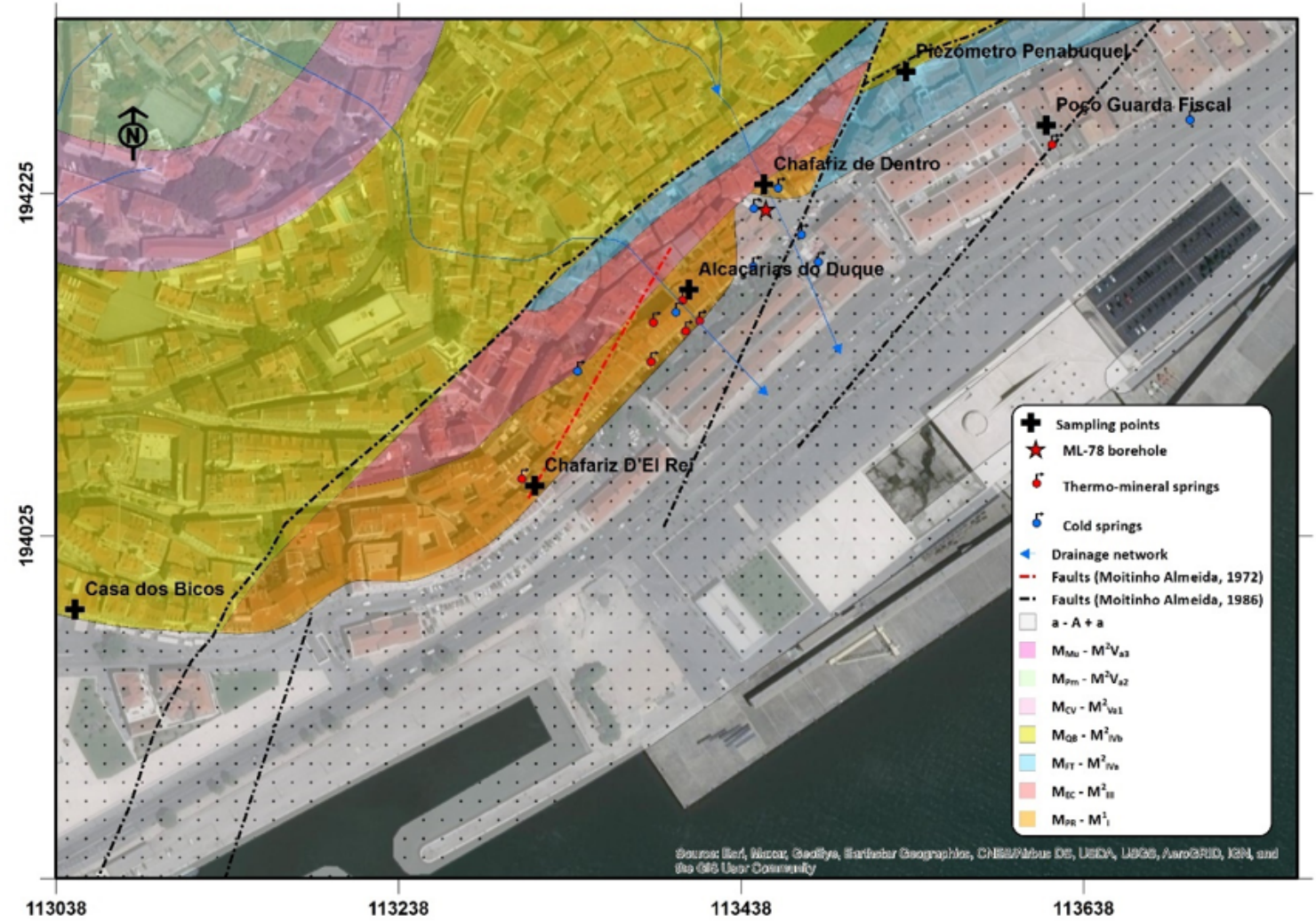

\section{Figure 5}

Location of water sampling points in the study area carried out over the Geological Map of Lisbon County, sheet 4, scale 1:10 000 (Moitinho de Almeida, 1986). Note: The designations employed and the presentation of the material on this map do not imply the expression of any opinion whatsoever on the part of Research Square concerning the legal status of any country, territory, city or area or of its authorities, or concerning the delimitation of its frontiers or boundaries. This map has been provided by the authors.

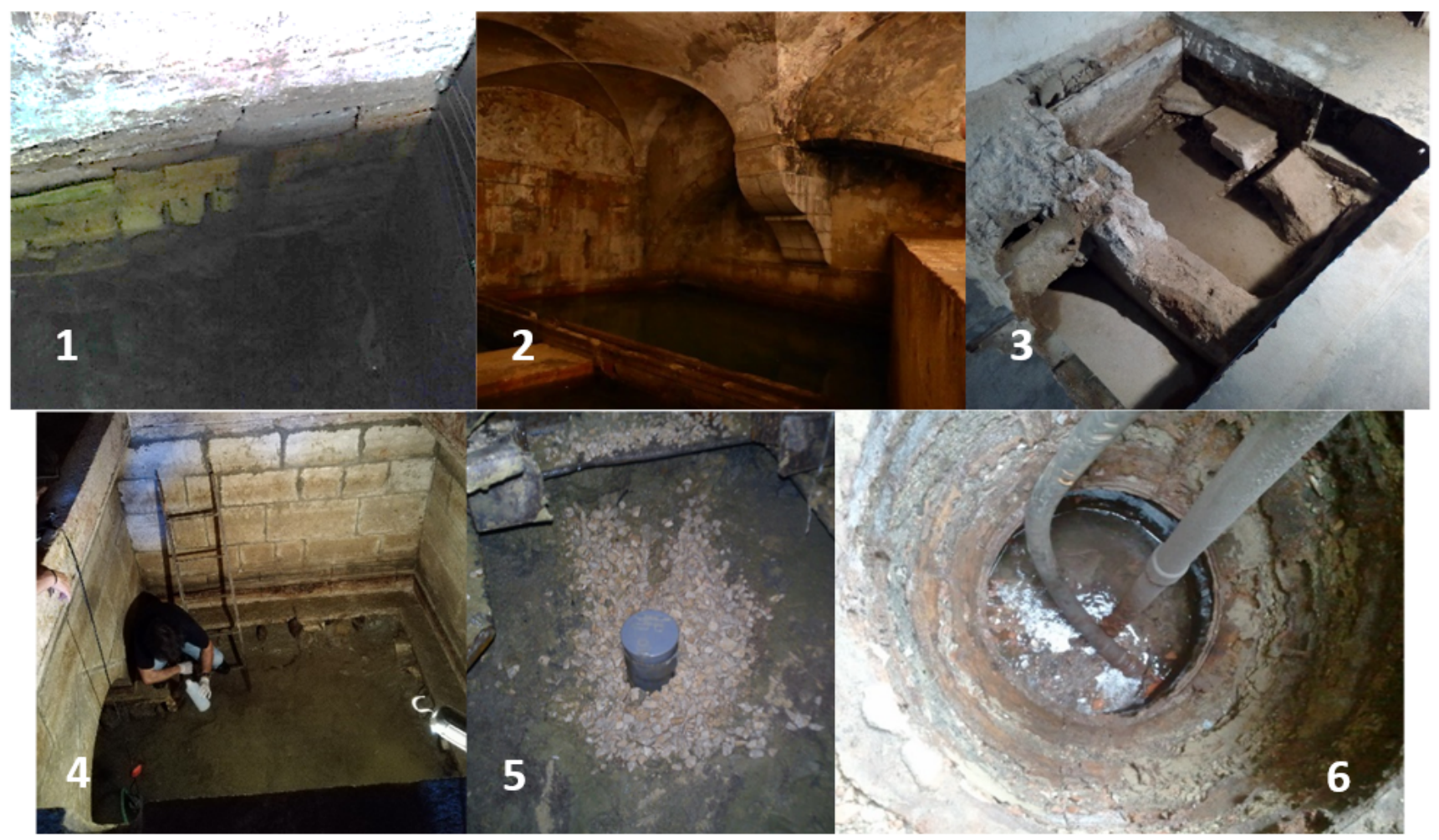

Figure 6 
Sampling points: 1 - Casa dos Bicos romain pool for garum; 2 - Chafariz D’El Rei water tank; 3 - Alcaçarias do Duque seepage inside the spa tub; 4 Chafariz de Dentro water tank; 5 - Beco do Penabuquel piezometer; 6 - Poço da Guarda Fiscal hand-dug well.

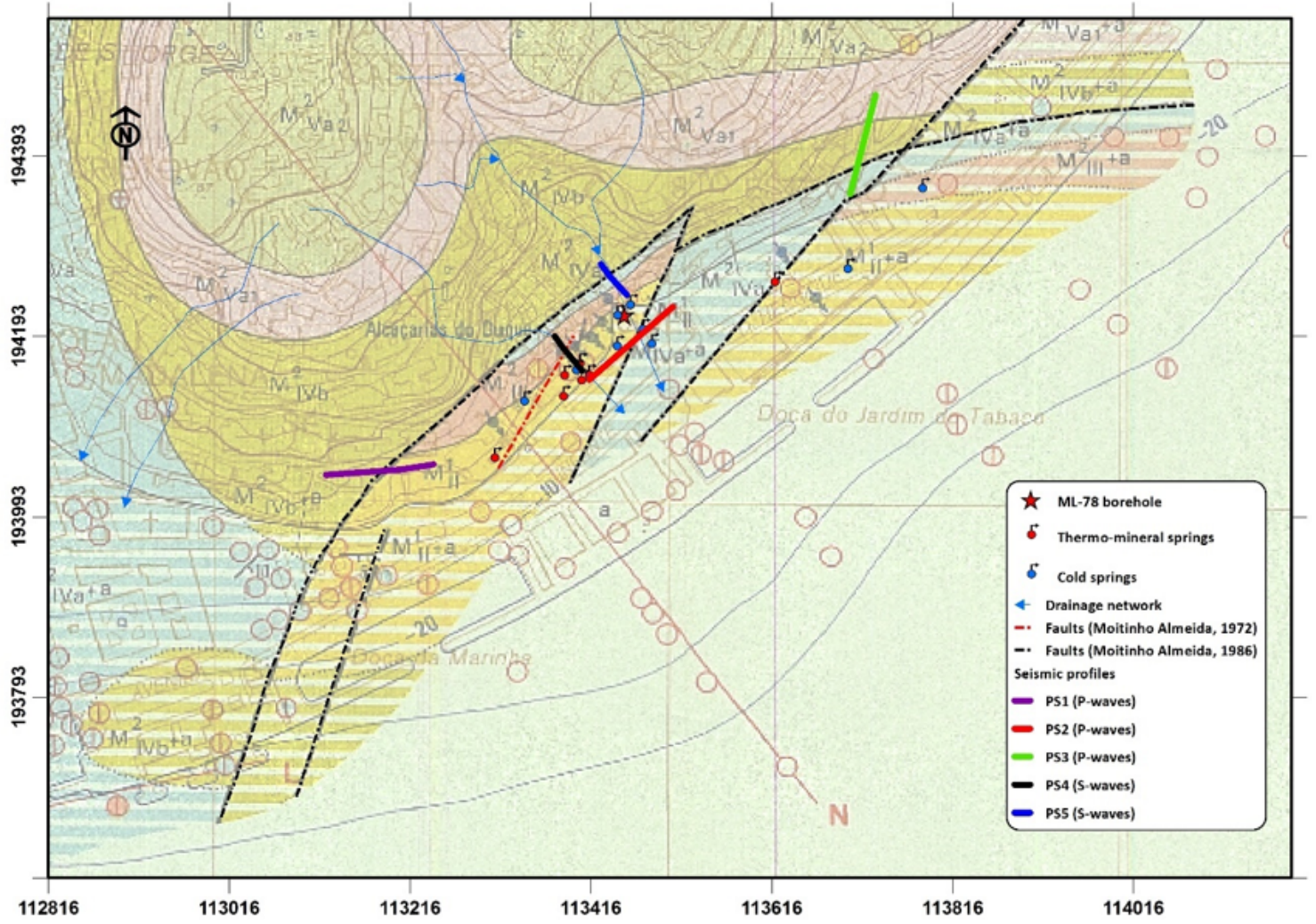

Figure 7

Location of the 5 seismic profiles carried out over the Geological Map of Lisbon County, sheet 4, scale 1:10.000 (Moitinho de Almeida, 1986). Note: The designations employed and the presentation of the material on this map do not imply the expression of any opinion whatsoever on the part of Research Square concerning the legal status of any country, territory, city or area or of its authorities, or concerning the delimitation of its frontiers or boundaries. This map has been provided by the authors.

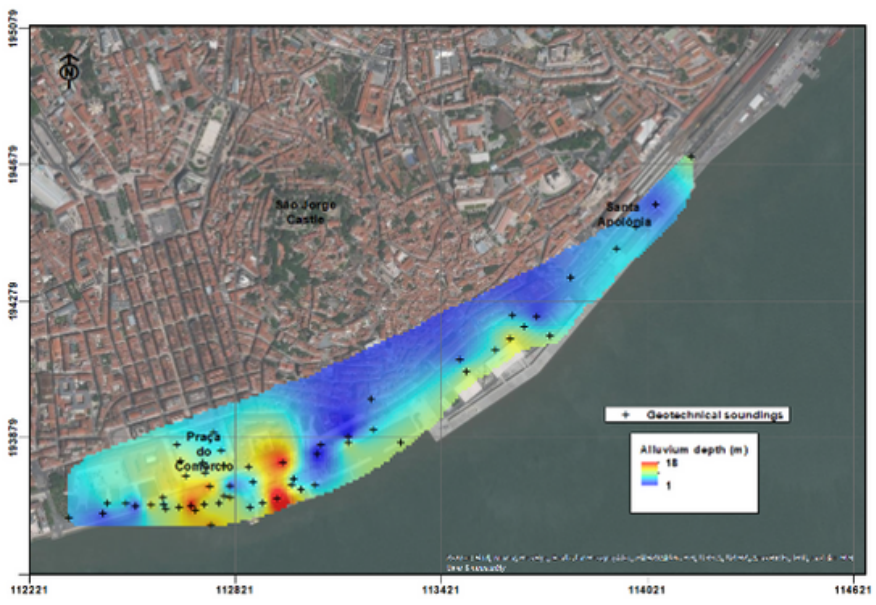

(A)

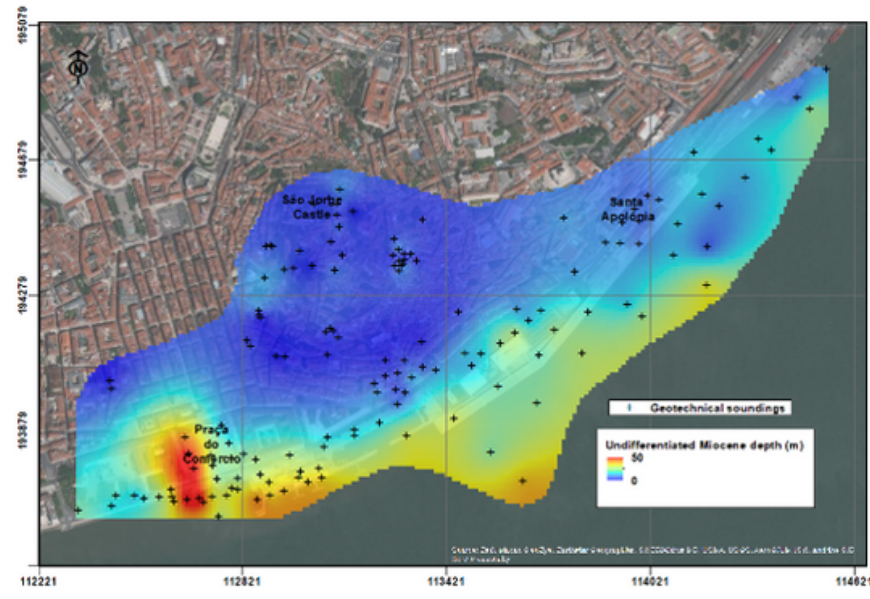

(B)

\section{Figure 8}

Isobaths maps and corresponding geotechnical soundings of (A) Top of Alluvium and (B) Top of Undifferentiated Miocene.Base: GoogleEarth Maps (C). Note: The designations employed and the presentation of the material on this map do not imply the expression of any opinion whatsoever on the part of Research Square concerning the legal status of any country, territory, city or area or of its authorities, or concerning the delimitation of its frontiers or boundaries. This map has been provided by the authors. 


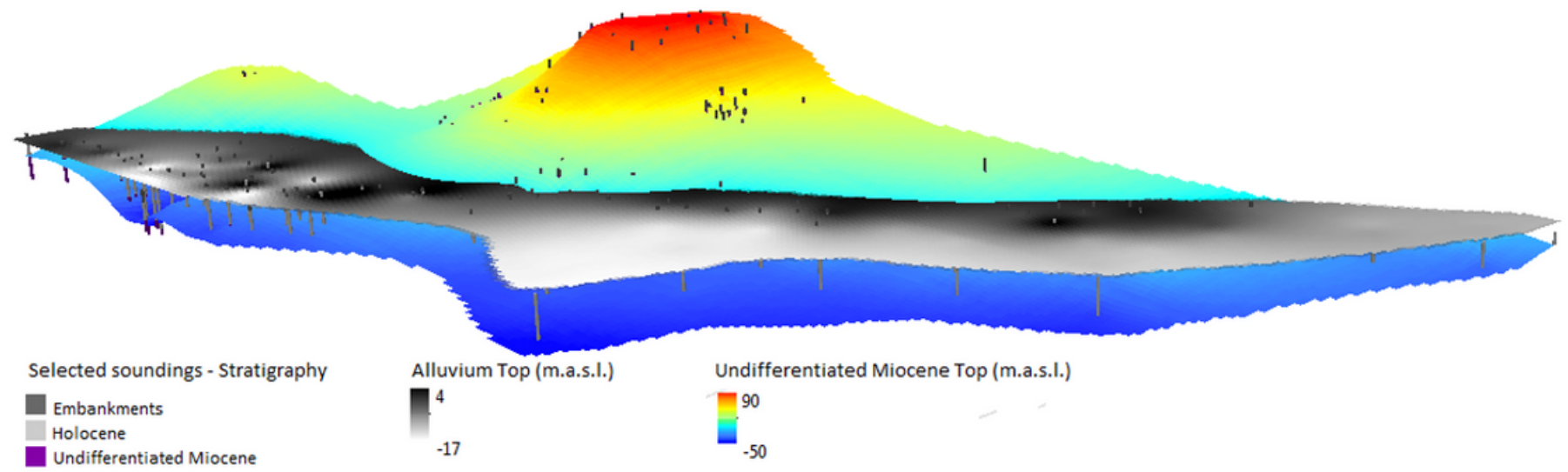

\section{Figure 9}

3D visualization of isohypses and corresponding soundings of Top of Alluvium and Top of Undifferentiated Miocene. Note: The designations employed and the presentation of the material on this map do not imply the expression of any opinion whatsoever on the part of Research Square concerning the legal status of any country, territory, city or area or of its authorities, or concerning the delimitation of its frontiers or boundaries. This map has been provided by the authors.

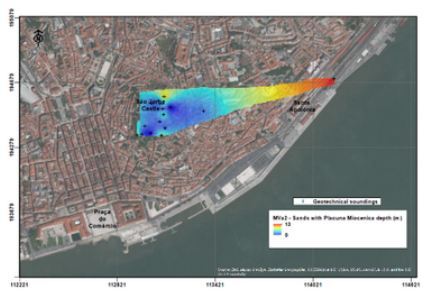

(A)

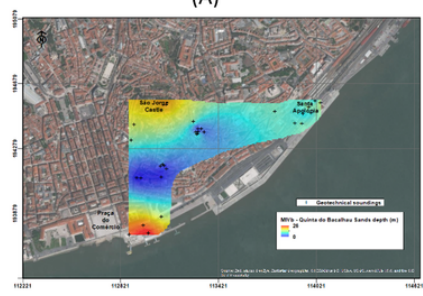

(C)

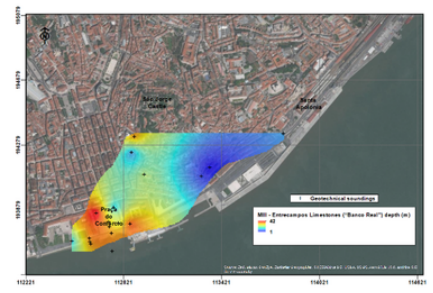

(E)

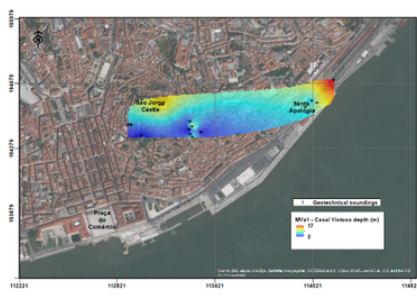

(B)

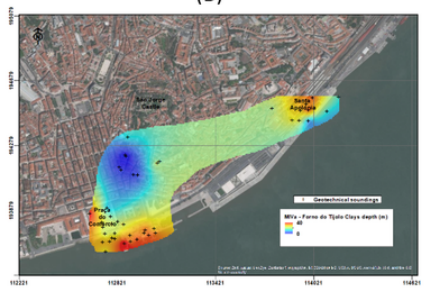

(D)

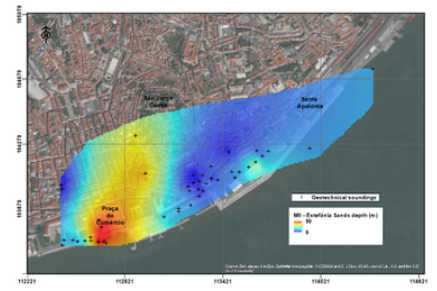

(F)

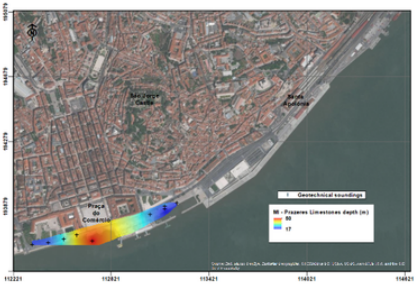

(G)

\section{Figure 10}

Isobaths maps and corresponding geotechnical soundings of top of (A) MVa2 - Sands with Placuna Miocenica; (B) MVa1 - Casal Vistoso; (C) MIVb - Quinta do Bacalhau Sands; (D) MIVa- Forno do Tijolo Clays; (E) MIII - Entrecampos Limestones ("Banco Real”); (F) MII - Estefânia Sands; (G) MI - Prazeres Limestones. Note: The designations employed and the presentation of the material on this map do not imply the expression of any opinion whatsoever on the part of 
Research Square concerning the legal status of any country, territory, city or area or of its authorities, or concerning the delimitation of its frontiers or boundaries. This map has been provided by the authors.

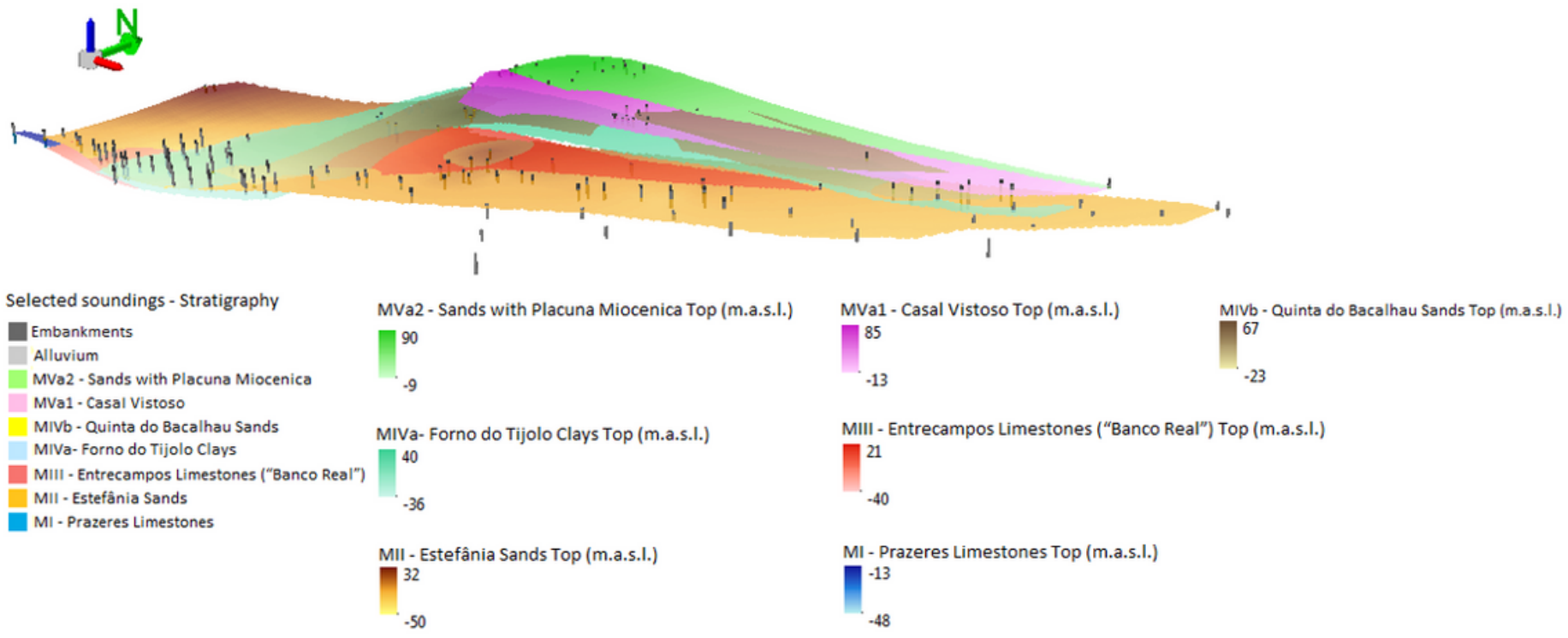

Figure 11

3D view of top of Miocene formations and corresponding geotechnical soundings Note: The designations employed and the presentation of the material on this map do not imply the expression of any opinion whatsoever on the part of Research Square concerning the legal status of any country, territory, city or area or of its authorities, or concerning the delimitation of its frontiers or boundaries. This map has been provided by the authors.
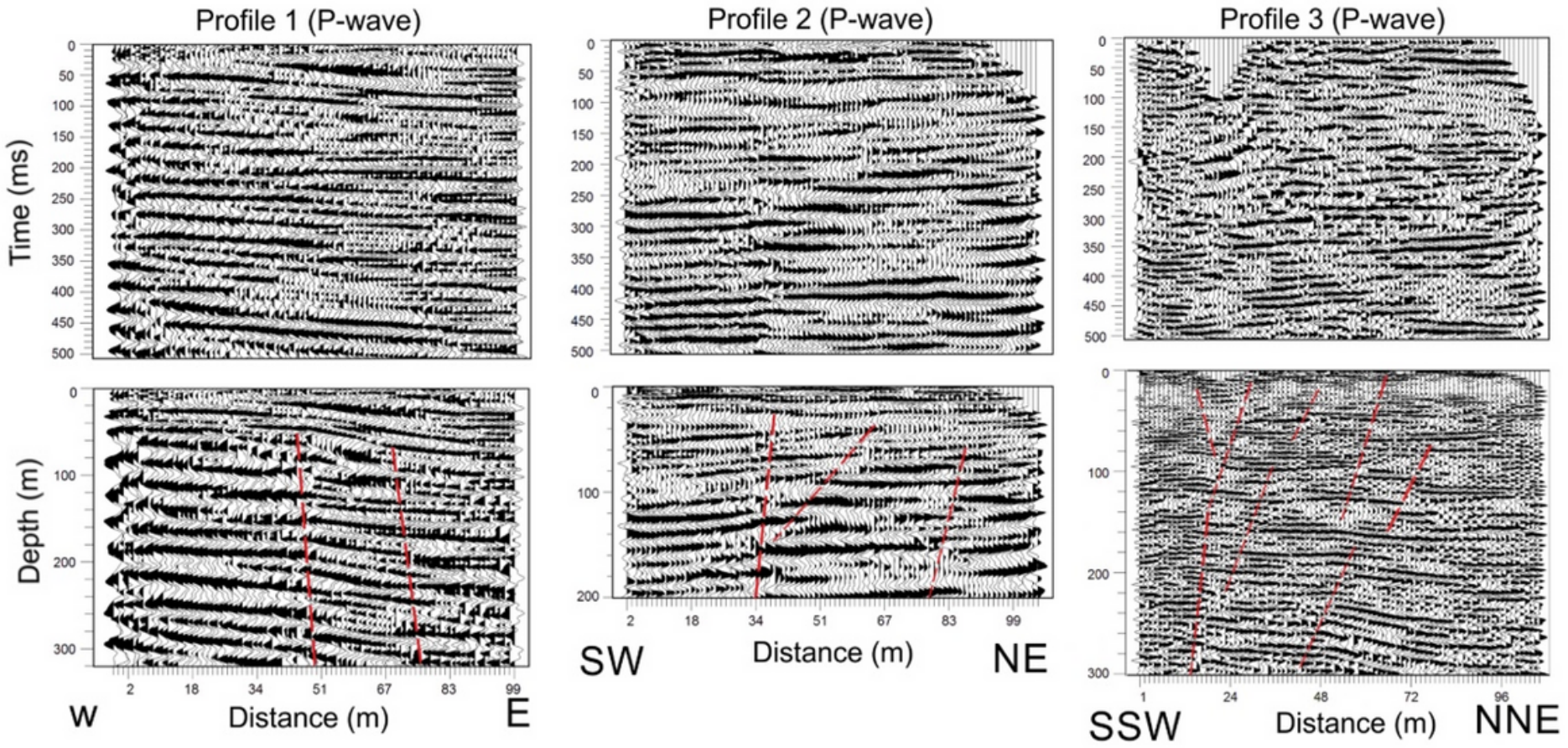

Figure 12

Time-migrated (top) and depth converted seismic sections with fault interpretation overlaid (bottom) of seismic P-wave Profiles 1, 2 and 3. 

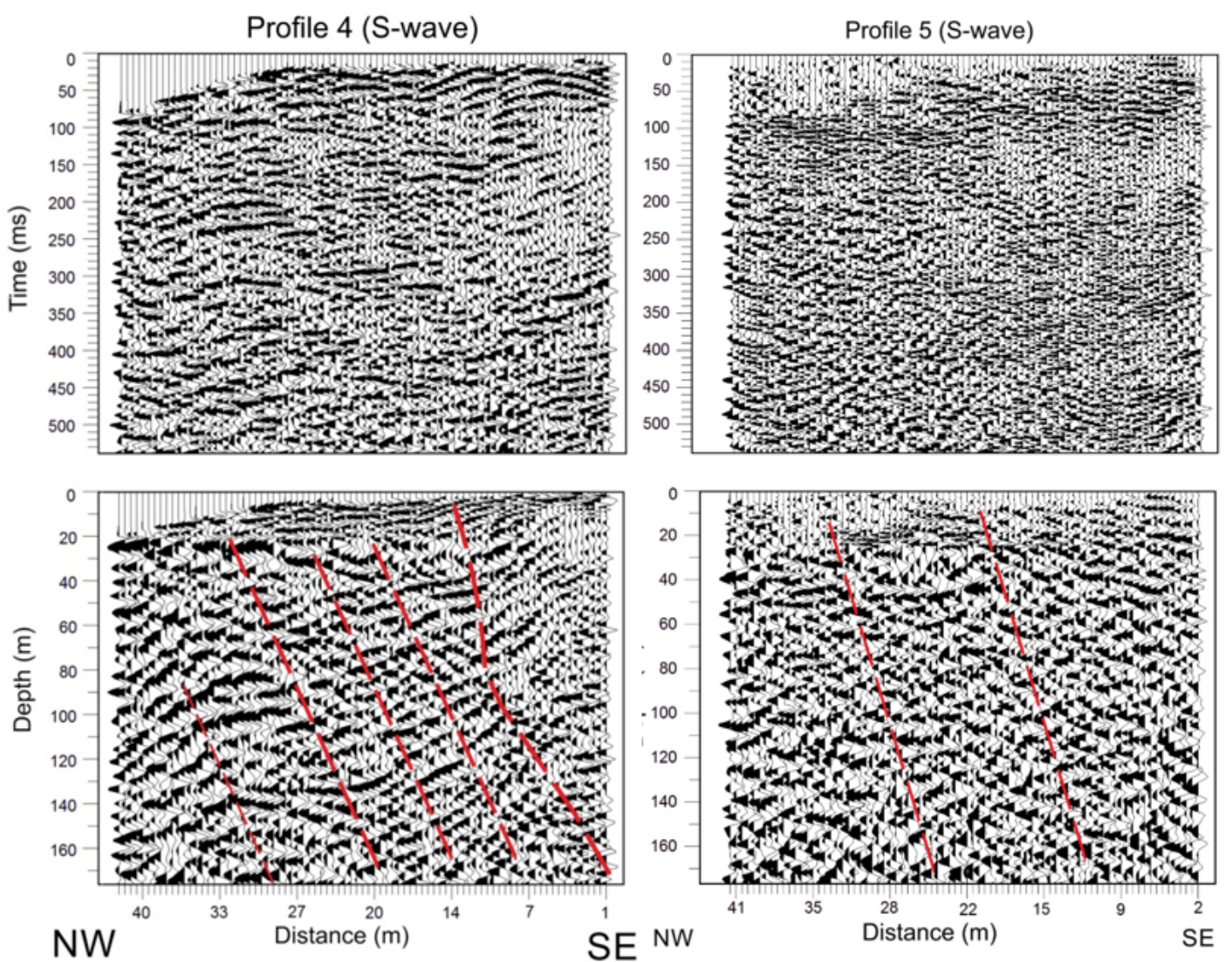

Figure 13

Time-migrated (top) and depth converted seismic sections with fault interpretation overlaid (bottom) of seismic S-wave Profiles 4 and 5. 

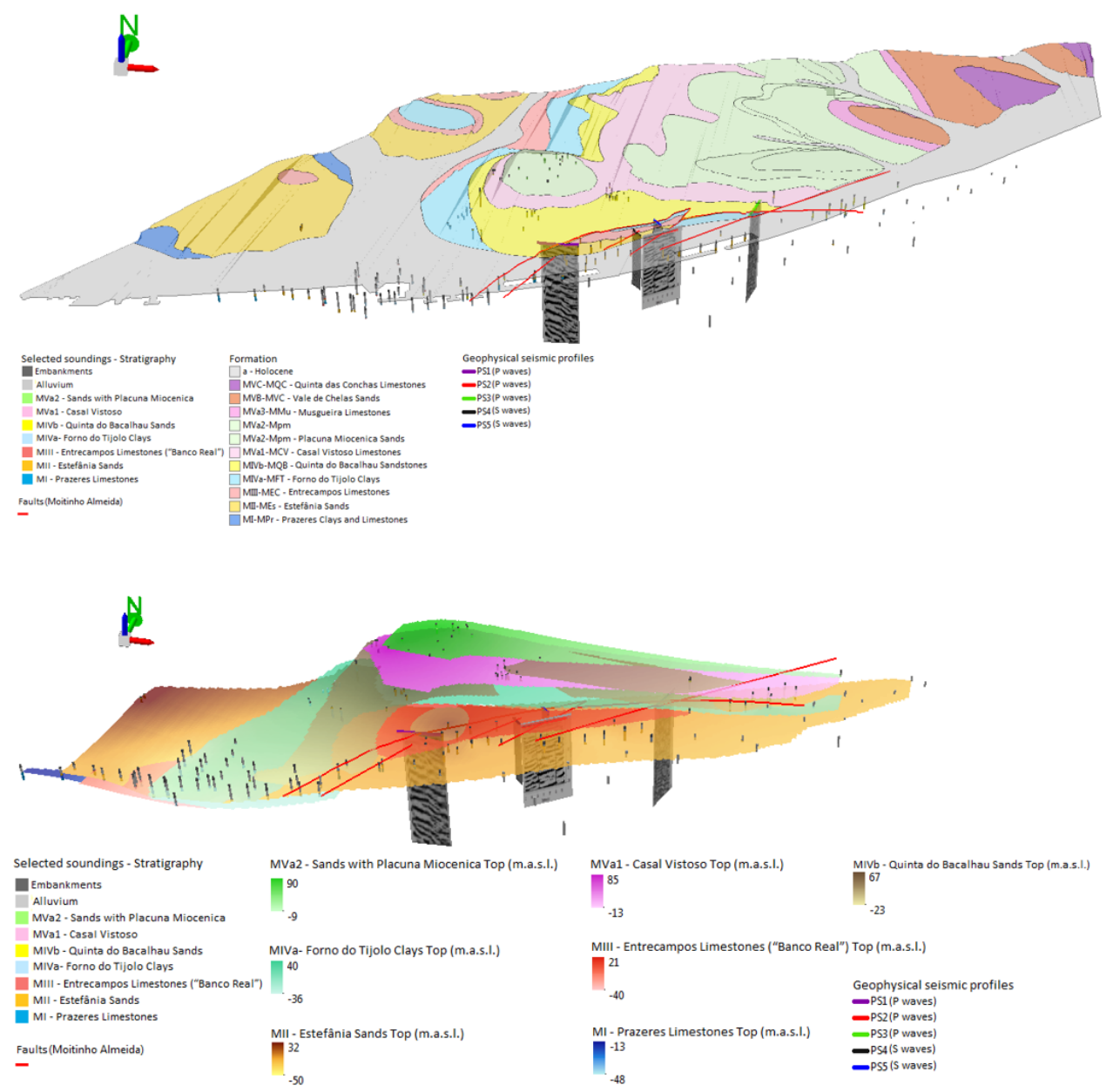

\section{Figure 14}

Two 3D view of the integrated information of selected geotechnical soundings, faults and seismic profiles over (up) the geological map (Moitinho de Almeida, 1972; Moitinho de Almeida, 1986) and (bottom) the modelled surfaces of the top of the Miocene formations. Note: The designations employed and the presentation of the material on this map do not imply the expression of any opinion whatsoever on the part of Research Square concerning the legal status of any country, territory, city or area or of its authorities, or concerning the delimitation of its frontiers or boundaries. This map has been provided by the authors. 


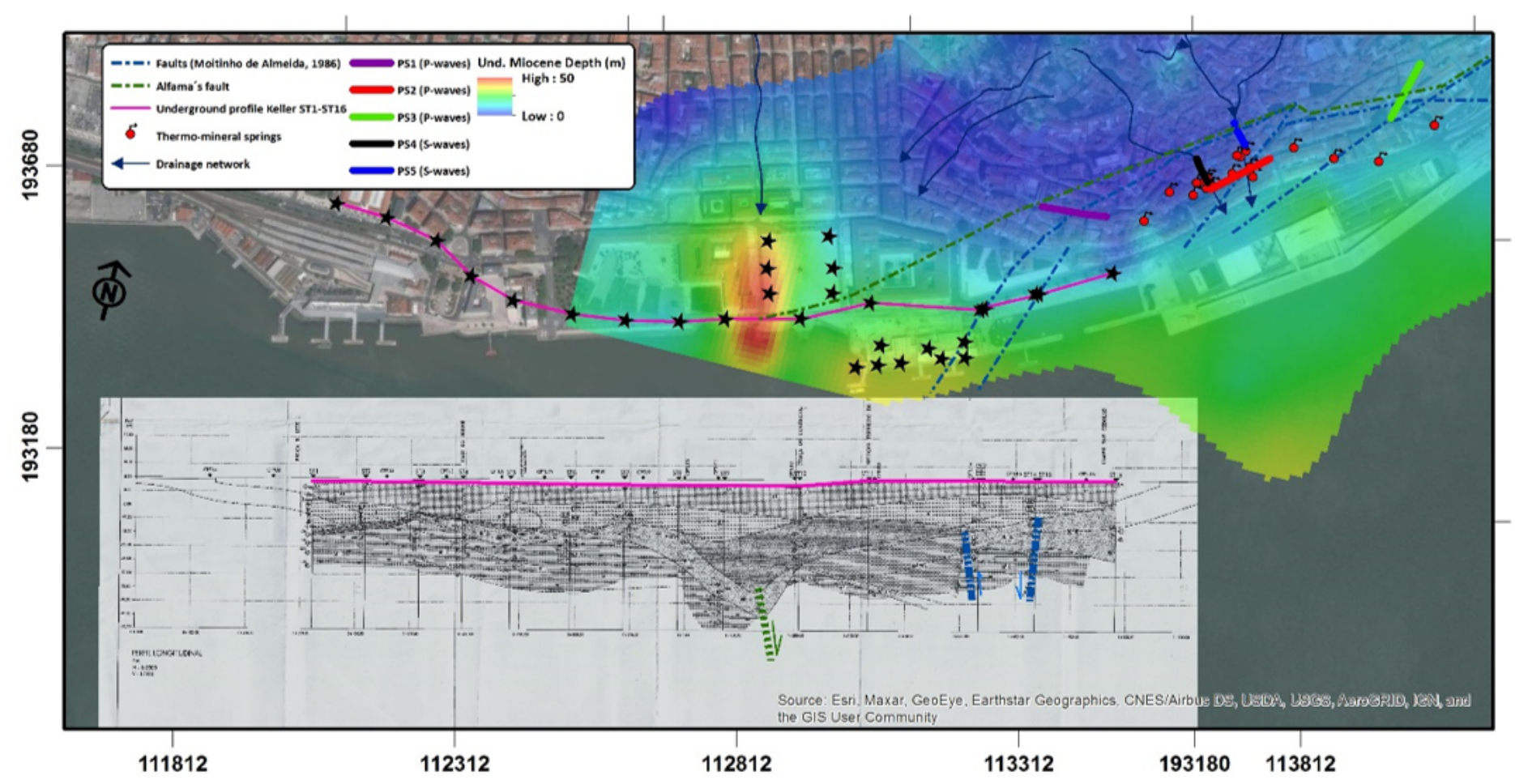

Figure 15

Map of the study area with Top Undifferentiated Miocene depth and geological section (pink line and stars) (Keller, Grundbau Gmbh, 1999) in the geological and geotechnical preliminary studies of the underground tunnel between Cais do Sodré and Praça do Comércio. Blue faults are shown in the cross-section and in the original map. Location of Alfama Fault (in green) as proposed in this work. Note: The designations employed and the presentation of the material on this map do not imply the expression of any opinion whatsoever on the part of Research Square concerning the legal status of any country, territory, city or area or of its authorities, or concerning the delimitation of its frontiers or boundaries. This map has been provided by the authors. 

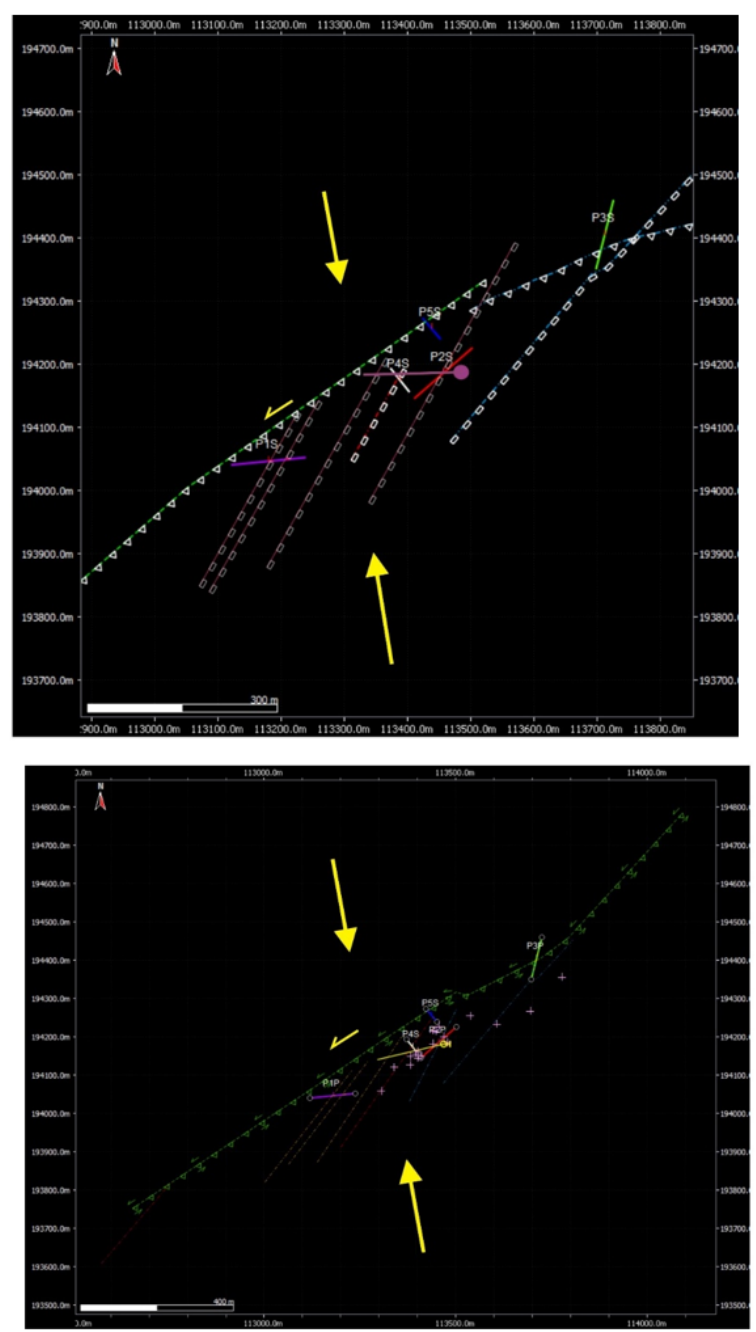

\section{Figure 16}

(Above) Structural geological map of the study area after the Geological Map of Lisbon County (Carta Geológica do Concelho de Lisboa 1:10 000, Moitinho de Almeida, 1986), with the faults controlling the emergence of the Alfama hot springs, and the faults and the line of the seismic profiles conducted in this study; (Below) Structural map of the study area proposed in this study from Moitinho de Almeida (1972), indicating faults from the 23702 report (pink) and an almost vertical inverse fault with left strike slip movement (green line) inferred from the geological, geophysical and geotechnical studies in the area. Note: The designations employed and the presentation of the material on this map do not imply the expression of any opinion whatsoever on the part of Research Square concerning the legal status of any country, territory, city or area or of its authorities, or concerning the delimitation of its frontiers or boundaries. This map has been provided by the authors. 


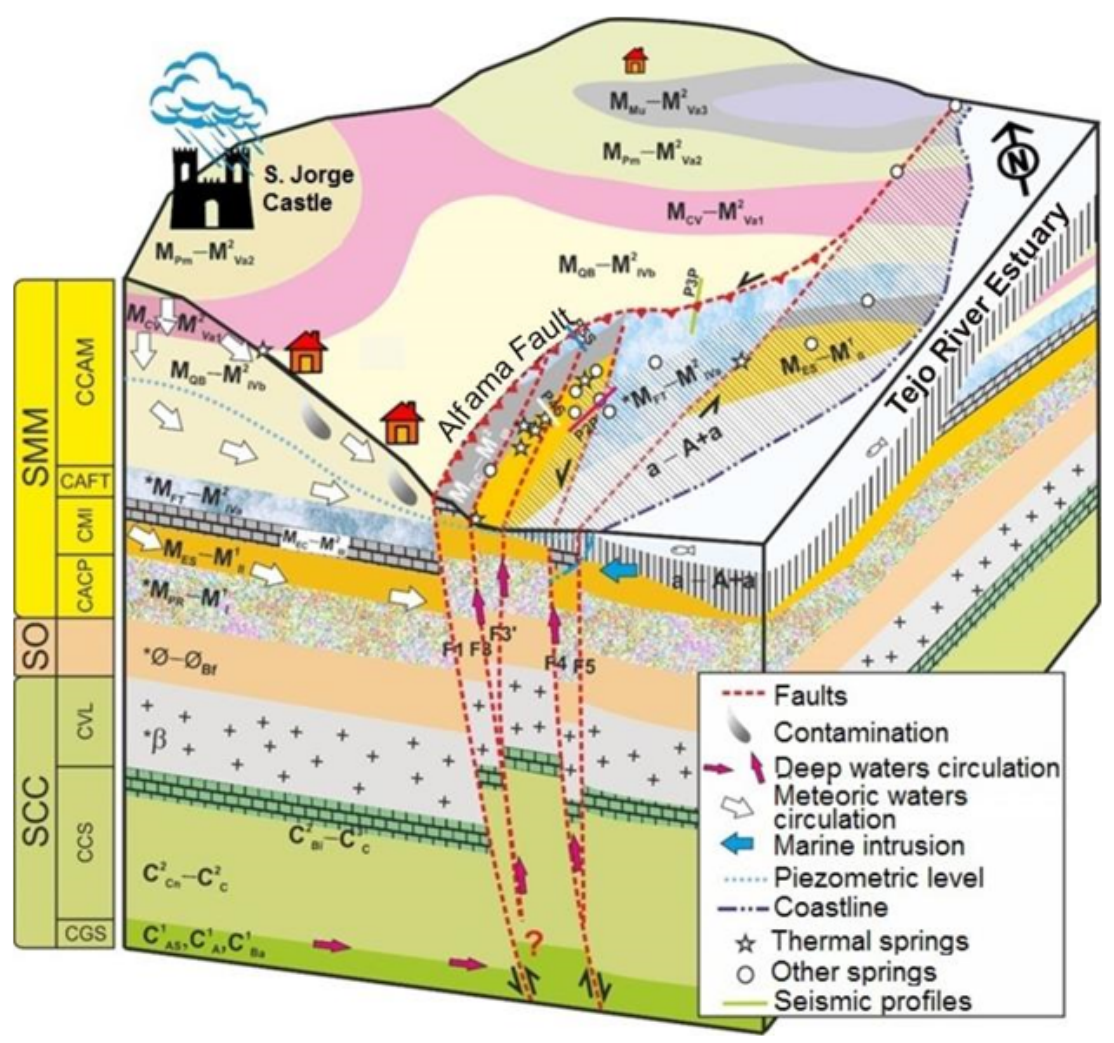

Figure 17

Conceptual hydrogeological 3D model of Alfama region (without scale, refined from Marrero-Diaz and Ramalho, 2015). Check Table 1 for hydrogeological subsystems acronyms and Figs. 3C and 3D for geological mapping colors. White arrows: probable groundwater circulation of the meteoric waters, infiltrated in the sands and limestones, circulating in the CCAM and in the CMI towards the Tagus River; Pink arrows: warm groundwater upwards circulation through the faults from CGS or deeper; Blue arrow: brackish estuarine water intrusion. Note: The designations employed and the presentation of the material on this map do not imply the expression of any opinion whatsoever on the part of Research Square concerning the legal status of any country, territory, city or area or of its authorities, or concerning the delimitation of its frontiers or boundaries. This map has been provided by the authors. 